INTER NATIONAL MONETARY FUND

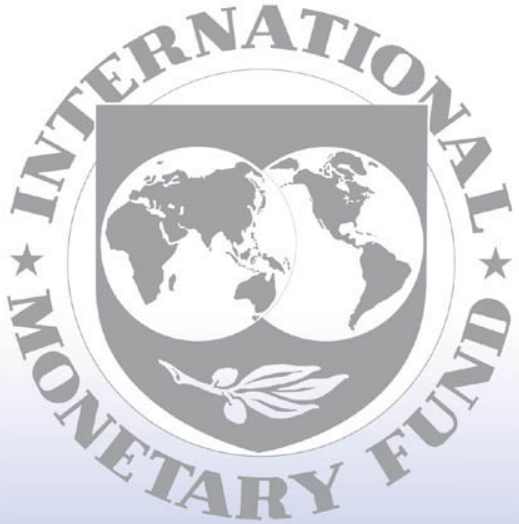

Staff

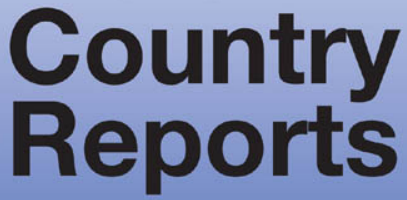




\section{Belgium: 2004 Article IV Consultation-Staff Report; Public Information Notice on the Executive Board Discussion}

Under Article IV of the IMF's Articles of Agreement, the IMF holds bilateral discussions with members, usually every year. In the context of the 2004 Article IV consultation with Belgium, the following documents have been released and are included in this package:

- the staff report for the 2004 Article IV consultation, prepared by a staff team of the IMF, following discussions that ended on November 22, 2004, with the officials of Belgium on economic developments and policies. Based on information available at the time of these discussions, the staff report was completed on January 26, 2005. The views expressed in the staff report are those of the staff team and do not necessarily reflect the views of the Executive Board of the IMF.

- a Public Information Notice (PIN) summarizing the views of the Executive Board as expressed during its February 18, 2005 discussion of the staff report that concluded the Article IV consultation.

The document listed below have been or will be separately released.

\section{Selected Issues Paper}

The policy of publication of staff reports and other documents allows for the deletion of market-sensitive information.

To assist the IMF in evaluating the publication policy, reader comments are invited and may be sent by e-mail to publicationpolicy@imf.org.

Copies of this report are available to the public from

International Monetary Fund • Publication Services

$70019^{\text {th }}$ Street, N.W. • Washington, D.C. 20431

Telephone: (202) 623-7430 • Telefax: (202) 623-7201

E-mail: publications@imf.org •Internet: http://www.imf.org

Price: $\$ 15.00$ a copy

\section{International Monetary Fund Washington, D.C.}


This page intentionally left blank

CInternational Monetary Fund. Not for Redistribution 
INTERNATIONAL MONETARY FUND

BELGIUM

Staff Report for the 2004 Article IV Consultation

Prepared by Staff Representatives for the 2004 Consultation with Belgium

Approved by Poul Thomsen and Michael Hadjimichael

January 26, 2005

The discussions took place in Brussels during November 12-22, 2004. The teamMessrs. Everaert (head) and Hofman and Mmes. Polan and Zhou (all EUR) - met with the prime minister, the governor of the central bank, the minister of pensions and their staffs; the head of the banking commission; the director of the treasury; staffs of the ministries of finance, the budget, employment, social affairs and health, and the economy; the High Finance Council; the Central Economic Council; the High Labor Council and staff of regional employment organizations; the Planning Bureau; academics, and representatives of labor unions, business organizations, and banks. Mr. Kiekens (Executive Director) and Ms. Dupont (Advisor) participated in the discussions.

At the time of the last Article IV consultation on February 13, 2004, the Executive Board stressed the need to reduce primary spending growth for successful fiscal consolidation and endorsed the focus on reducing public debt and promoting employment growth to cope with population aging.

Belgium accepted the obligations under Article VIII and, apart from certain security restrictions, maintains an exchange system free of restrictions (Appendix I).

Belgium subscribes to the Fund's Special Data Dissemination Standard, and comprehensive economic data are available on a timely basis (Appendix II).

The concluding statement of the mission is publicly available at http://www.imf.org/external/np/ms/2004/112204.htm

A Financial Stability Assessment is under way; its findings will be discussed at the time of the next Article IV consultation. 


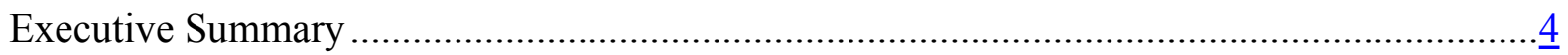

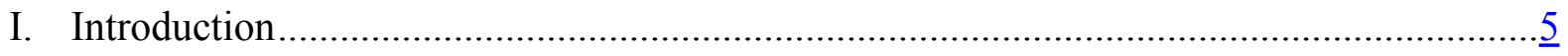

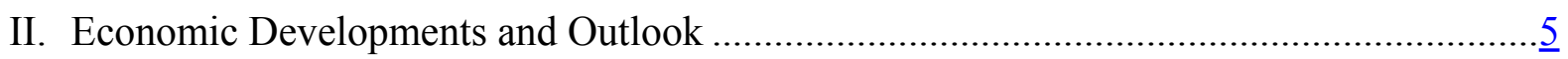

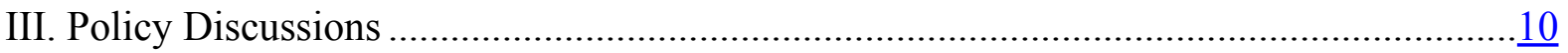

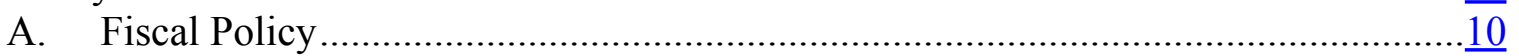

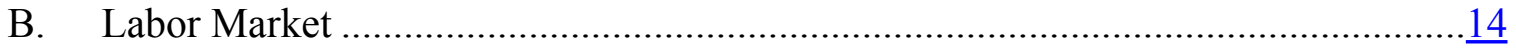

C. Product Markets, Financial Sector, and Other Issues .............................................17

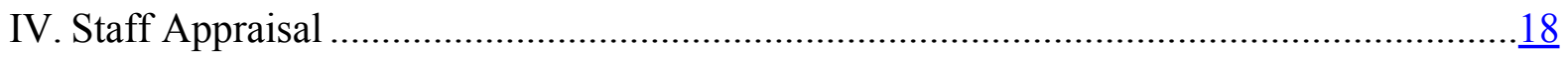

Figures

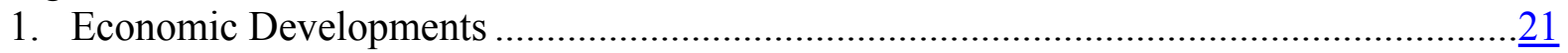

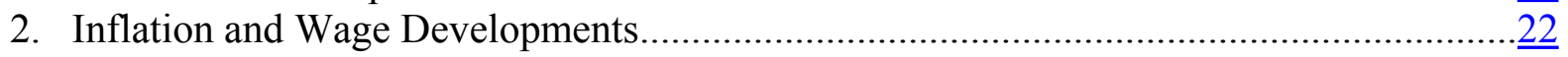

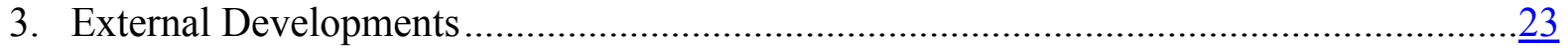

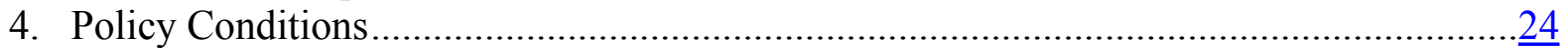

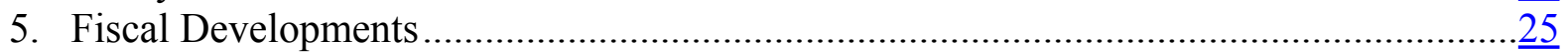

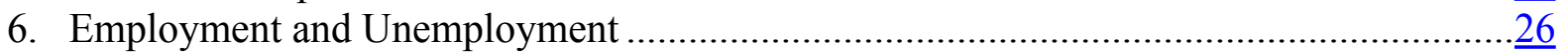

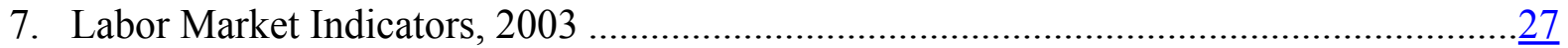

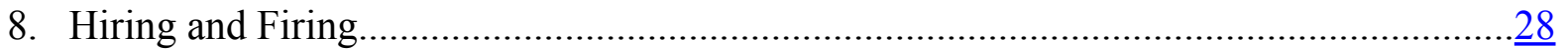

Tables

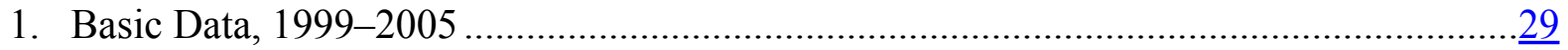

2. Operations of the General Government, 1997-2003 …….............................................

3. Public Sector Debt Sustainability Framework, 1999-2009 ……………............................

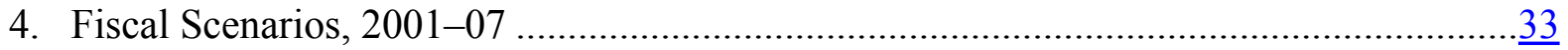

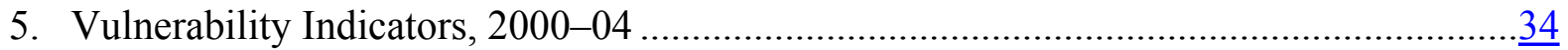

Text Boxes

1. Past Fund Policy Recommendations and Implementation................................................ $\frac{5}{7}$

2. Why has the Recovery in Household Consumption been so Strong? .................................

3. Coping with Population Aging ..............................................................................

4. Labor Market Institutions Impede the Effectiveness of Tax Cuts in Raising Employment

\section{Text Tables}

1. Selected Indicators of Economic Activity ……….............................................................

2. Budget Balance Adjusted for Cycle and Nonstructural Items .........................................11

3. Interprofessional Wage Agreements, 1997-2006 ......................................................... 
Appendices

1. Fund Relations .

35

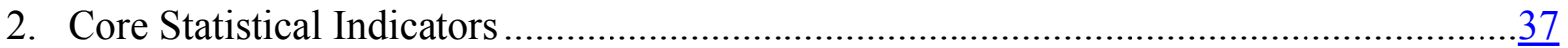




\section{Executive Summary}

Economic growth has been comparatively robust, propelled by household spending and supportive policies, and yielding an auspicious outlook for 2005. Private consumption is set to continue to drive growth, helped by income tax cuts, low interest rates, rising house and equity prices, and spending linked to the repatriation of financial assets due to a tax amnesty and the EU savings-taxation directive. Corporate investment and employment growth are likely to strengthen, though risks lie in euro appreciation and faltering trading partner demand. The inflation outlook is in line with that of the euro area, with indirect tax increases providing a transitory boost.

Policies are correctly geared toward attenuating the long-term impact of population aging on growth and public finances, but fiscal and labor market reforms should be stepped up substantially and concurrently:

- With large primary surpluses and budgets at least in balance over the past five years, fiscal consolidation has progressed, as indicated by a declining public debt-to-GDP ratio. However, one-off measures continue to play a role in achieving budget objectives, and the primary surplus has declined recently amid spending pressures and tax cuts. To avoid the return of deficits and achieve needed surpluses, focus should shift decisively toward durable primary expenditure restraint. The budgetary framework and the internal stability pact between federal and regional governments will need to be reinforced.

- Past reforms have delivered a sustainable pension system, but the retirement decision remains to be made actuarially fair, and early retirement schemes need to be phased out. Measures to correct health care expenditure overruns are in place, but policies to curb underlying spending growth in the medium run should be implemented. Structural reforms in other spending areas (civil service, labor market programs) are urgent.

- While raising comparatively low employment rates is a priority, the authorities' desire to preserve social peace implies a gradual approach. Ongoing reductions in the labor tax wedge, the introduction of an earned income tax credit, and the actual and proposed measures to limit recourse to early retirement will be helpful. The staff sees a need for more comprehensive reforms to the current social bargaining model to raise the effectiveness of these measures in boosting job creation and increase wage and labor market flexibility.

In product markets, ongoing reforms should be accelerated to strengthen effective competition, de facto liberalize network industries, and reduce further the administrative burden on businesses and taxpayers.

The financial sector has performed well, though the life insurance sector continues to face challenges. The merger of banking and insurance supervisors is progressing apace. A Financial Sector Assessment Program has started and will be completed in the context of the next Article IV consultation. 


\section{INTRODUCTION}

1. Discussions took place against the background of a robust economic recovery and policies focused on addressing the long-term challenges of population aging. Persistent fiscal consolidation has led to a rapid decline in the public debt-to-GDP ratio, while pension reforms are mitigating the impact of aging on the budget. Nonetheless, past Fund recommendations to curb real primary spending growth and achieve jointly fiscal surpluses and higher labor utilization and economic efficiency still apply (Box 1).

\section{Box 1. Belgium: Past Fund Policy Recommendations and Implementation}

The authorities have been receptive to Fund recommendations and conduct an open and frank dialogue with staff. While generally in agreement with the direction of the Fund's advice, they remain to be convinced of the need to modify the welfare system through comprehensive reform and of the feasibility to do so while preserving social peace. They also note that the federal structure of the country and related interregional sensitivities constrain the scope and speed of reform. Against this background, implementation of Fund advice has been slow-paced and remains incomplete.

Fiscal policy. In line with recommendations, impressive fiscal consolidation has been achieved since the early 1990s. More recently, the Fund has continued to strongly support the authorities' twin objectives of further fiscal consolidation and the reduction of the still-high tax burden, but argued that achieving these goals required a durable reduction in primary spending growth, an area in which the authorities have yet to deliver. Progress toward building fiscal surpluses has been slower than recommended. To facilitate the attainment of these objectives, the Fund has called for a medium-term budget framework based on expenditure ceilings, while the authorities continue to focus on achieving annual nominal balance targets.

Labor and product markets. The Fund has supported the authorities' efforts to reduce the labor tax wedge and argued for a coherent program of deep structural reform, in particular of unemployment benefits, early retirement arrangements, and features of the wage bargaining system to enhance interregional labor mobility and wage dispersion. Progress in these areas is incomplete. In product markets, the Fund has urged a more rapid pace of liberalization - which did not materialize, but the authorities are complying with timelines set by the EU.

Recommendations to reduce the administrative burden and strengthen e-government were broadly followed.

Financial sector. Reforms and strengthening of financial sector supervision have been consistent with Fund advice.

\section{ECONOMIC DEVELOPMENTS AND OUTLOOK}

2. Economic growth has recently been stronger than in trading partners, driven by household spending on consumption and residential construction (Figure 1 and Text Table 1). While temporary deviations of growth from the euro area average are common, given the dominance of the more volatile intermediate output in economic activity, growth in 
Text Table 1. Belgium: Selected Indicators of Economic Activity

(Percent change from previous period; unless otherwise indicated)

\begin{tabular}{|c|c|c|c|c|c|c|c|c|c|c|}
\hline & \multirow[b]{2}{*}{2001} & \multirow[b]{2}{*}{2002} & \multirow[b]{2}{*}{2003} & \multicolumn{4}{|c|}{2003} & \multicolumn{3}{|c|}{2004} \\
\hline & & & & Q1 & Q2 & Q3 & $\overline{\mathrm{Q} 4}$ & Q1 & Q2 & Q3 \\
\hline Real GDP growth & 0.9 & 0.9 & 1.3 & 0.2 & 0.1 & 0.7 & 0.7 & 0.7 & 0.8 & 0.7 \\
\hline Domestic demand & 0.2 & 0.6 & 1.6 & -0.4 & -0.8 & 2.2 & 1.0 & 0.9 & -0.1 & 2.6 \\
\hline Private consumption & 0.7 & 0.3 & 2.2 & 0.4 & 0.7 & 0.5 & 0.2 & 0.8 & 0.5 & 0.6 \\
\hline Fixed investment: business & 3.6 & -3.8 & -1.9 & -0.7 & -1.7 & -3.1 & 0.4 & 4.8 & -3.3 & 9.9 \\
\hline Fixed investment: dwelling & -3.4 & -3.3 & 2.6 & 1.6 & 1.6 & 0.3 & -1.1 & 0.4 & 1.2 & -0.6 \\
\hline Stockbuilding $1 /$ & -0.9 & 0.7 & -0.1 & -1.1 & -1.2 & 2.1 & 1.1 & -0.6 & -0.2 & 0.5 \\
\hline Net exports 1 / & 0.6 & 0.3 & -0.3 & 0.6 & 0.9 & -1.4 & -0.3 & -0.2 & 0.9 & -1.8 \\
\hline Exports & 1.8 & 1.3 & 1.7 & -0.9 & 1.1 & -0.1 & 1.3 & 0.4 & 0.9 & 5.7 \\
\hline Imports & 1.0 & 1.0 & 2.1 & -1.7 & 0.1 & 1.6 & 1.7 & 0.6 & -0.1 & 8.1 \\
\hline Unemployment (percent) & 6.7 & 7.3 & 8.1 & 7.9 & 8.1 & 8.2 & 8.3 & 8.5 & 8.6 & 8.6 \\
\hline
\end{tabular}

Sources: NBB Statistical Bulletin; and Fund staff estimates.

1/ Contribution to GDP growth.

excess of partner countries during a prolonged period is atypical. The authorities emphasized their credible balanced-budget tax reduction strategy as a key support for consumption, while recognizing that a range of factors were at play (Box 2). The improvement in the global outlook was also essential, but the response of business investment has been uneven and export growth lower than expected in relation to partner country demand. Employment has yet to pick up in earnest, though it has held up better than in the previous cycle.

\section{Differences between national and euro area inflation are short-lived and mainly} due to indirect taxes and energy prices (Figure 2). The former exercised downward pressure in 2002-03 (as the TV license fee was cut) and upward pressure in 2004-05 (with rising energy and tobacco taxes). The response of inflation to oil prices has been stronger than in the euro area because of larger weights and less prevalent excise duties. Underlying inflation has declined due to the negative, albeit narrowing, output gap, moderating wage growth, and gradual pass-through of euro appreciation. However, it is expected to rise somewhat in the near term owing to higher raw material prices and indirect taxes. Studies by the authorities found no structural factors (e.g., differences in response to shocks) that would lead to significant cumulative deviations of inflation from the euro area average, concluding that a common monetary policy had thus far been well suited for Belgium.

\section{The external position remains strong, though there has been a slight erosion of} competitiveness vis-à-vis key trading partners (Figure 3). It was agreed that the decline in global export market share was not worrisome, in particular as Belgium's share of EU exports had held up well. Participation in EMU had gone smoothly so far, given the close link of the economy to the core euro area and the discipline imposed by the prior peg to the deutsche mark. Nonetheless, there had been a modest real appreciation over the past two years as relative wage increases were not entirely offset by productivity growth, especially with respect to France, Germany, and the Netherlands combined. The staff, while recognizing that the current account surplus had remained close to 4 percent of GDP, noted that it would be important that future wage bargaining outcomes prevent further erosion of competitiveness ( $\mathbb{\| 1 9 )}$. 


\section{Box 2. Belgium: Why has the Recovery in Household Consumption been so Strong?}

Robust private consumption has been the main force underpinning the recovery since 2003. In real terms it rose by 2.4 percent in 2003 and by 2.6 percent (annualized) during the first three quarters of 2004.

Real disposable income growth declined, thus playing a lesser role, even though it exceeded that of neighboring countries. Employment, while not rising, held up better than in previous downturns, moderate wage growth continued, and tax cuts helped.

Consequently, the factors contributing to the resumption in the declining trend in the household savings rate, after its marked increase in 2001-02, have been key:

- Confidence effects from continuing balanced budgets. Such an outcome, achieved even in the downturn, reaffirmed the authorities' ability to pursue the trend improvement in public finances as measured by the fall in the public debtto-GDP ratio. This trend is thought to be associated with the steady decline in private saving since 1993.

- Anticipation of the impact of the ongoing multiyear tax reform. This reform will reduce income taxes permanently by slightly more than 1 percentage point of GDP, with the largest effect on disposable income to be felt in 2005-06.

- Wealth effects from house and financial asset prices. Unlike in Germany and the Netherlands, but similar to France, house prices have been increasing steadily since 2001, by about 6 percent per year in real terms during 2002-03. Reductions in the gift tax and property transaction costs in some regions are contributing factors. Although the direct impact of gains in housing wealth is limited by the lack of mortgage equity withdrawal possibilities and the small secondary housing market, rising housing wealth could well have contributed indirectly by boosting consumer confidence. In addition, the decline in household financial assets ended in 2003 with the stabilization of equity markets, thus removing a drag on consumption.

- Spending of repatriated capital in anticipation of the upcoming implementation of the EU savings tax directive and in connection with the 2004 tax amnesty.

- Low interest rates, directly reducing the cost of consumer credit and indirectly lowering debt payments on new and refinanced mortgage loans, though refinancing of existing mortgages is limited because of transaction costs. 


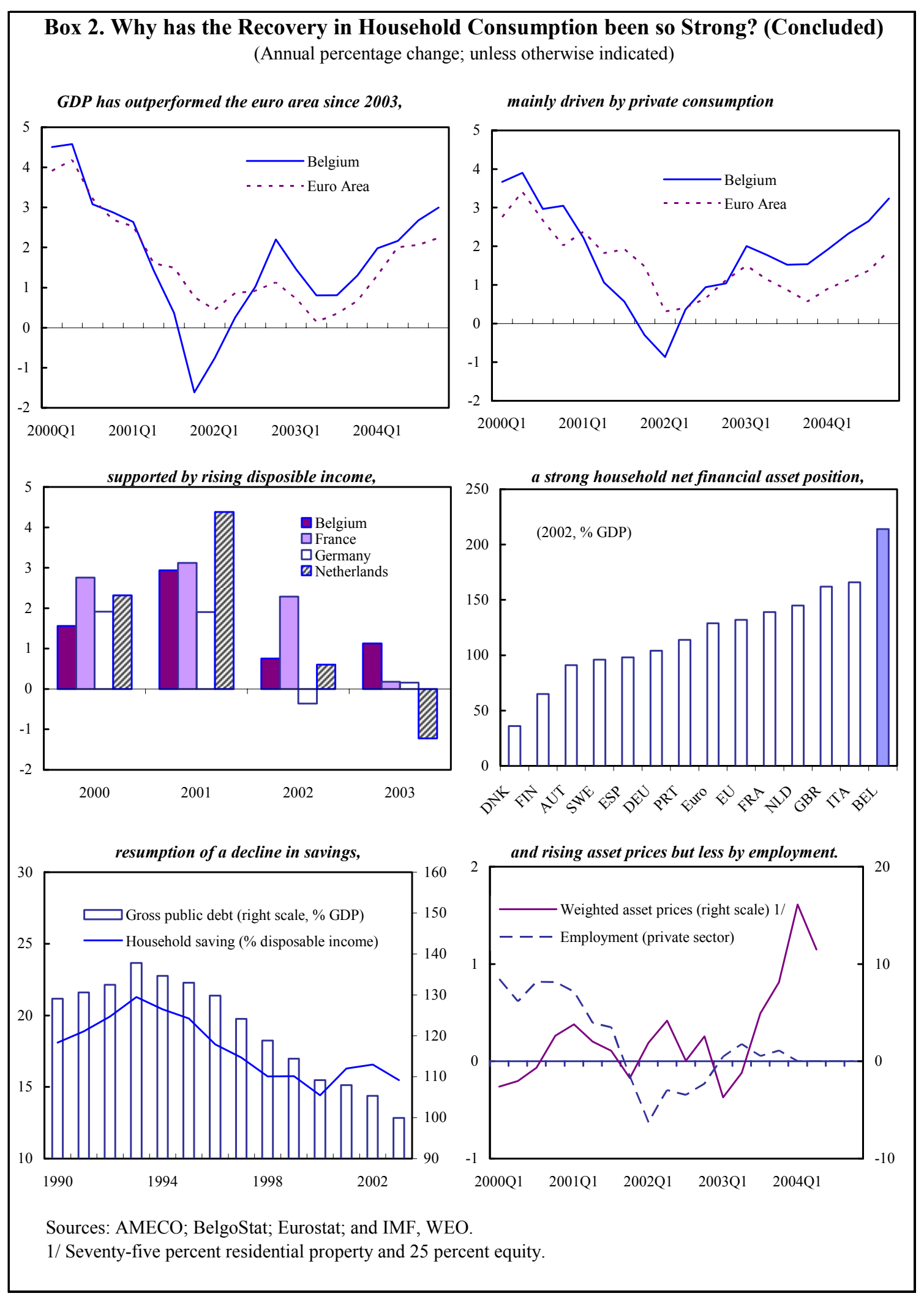


5. Policy conditions have been supportive (Figure 4). Traditional indicators, such as a Taylor rule and monetary conditions index, point to accommodating conditions. ${ }^{1}$ The authorities emphasized, however, that such indicators were too mechanical to allow a balanced judgment of the appropriateness of the policy stance. Other data continued to signal slack. Capacity utilization had risen, but not beyond its historic average. House and equity prices were also increasing, though at what appeared to be a sustainable pace. Price-earnings ratios had only recently caught up with elsewhere and were only slightly above historic averages. It was agreed that fiscal policy had been more supportive than apparent from the continuously balanced budgets during the cycle, especially in 2003, as the size of favorable one-time items had varied countercyclically.

\section{The authorities and staff saw the near-term outlook as auspicious, though} subject to several risks. Real GDP was expected to grow at a pace of about 2.5 percent throughout 2005, equivalent to about 2.2 percent if the lower number of working days in 2005 is taken into account. ${ }^{2}$ Private consumption would continue to drive growth, supported by ongoing tax cuts and rising employment and followed by a sustained uptick in investment. Oil prices constituted a key risk, especially if they were to slow global growth, and would be compounded by weakness in trading partners or further euro appreciation resulting from the unwinding of global current account imbalances. Domestically, the 2005-06 interprofessional agreement yielded moderate wage increases (partners agreed on January 18, 2005 on an average nationwide cumulative increase of 4.5 percent for the period 2005-06). Nonetheless, there are downside risks stemming from a slower pickup in employment and adverse confidence effects. Regarding the latter, the authorities underscored the need to preserve confidence in the sustainability of public finances by continuing to deliver budgets that were at least balanced.

\section{Population aging will reduce long-term growth, but policies and other factors} could play a mitigating role. The demographic effect is estimated to reduce potential GDP growth by about 1 percentage point from 2010 onward. The evolution of productivity is a key imponderable, with the authorities anticipating that labor productivity growth will rise from 1 percent in the mid-1990s to 1.75 percent during 2009-30. The staff noted that this implied either a sharp increase in total factor productivity growth or substantial capital deepening and preferred to be more conservative, while recognizing that substantial, though yet to be implemented, structural reforms could yield such an outcome. The productivity assumption matters a great deal for the long-run budgetary impact of aging in Belgium because pensions adjust with prices, but wages - the basis for contributions - can be expected to follow productivity. EU enlargement and globalization, while possibly increasing relocations in the short run, were seen by the authorities and employers as positive for long-run growth.

\footnotetext{
${ }^{1}$ A Taylor rule with 50/50 weights on inflation and unemployment and a neutral rate of 2 percent would indicate that conditions were 150 basis points too loose.

${ }^{2}$ Throughout this report, the staff projections are presented on an actual working-day basis.
} 


\section{Policy Discussions}

8. Discussions focused on the authorities' strategy to deal with population aging. There was agreement on the objectives for fiscal consolidation and increased labor utilization and on the need to strengthen policies to achieve them. The staff called for broader and expeditious action, while the authorities emphasized the importance of consensus-building and social peace, which demanded gradualism. Of the multiple prongs of the authorities' approach, fiscal consolidation had been proceeding well until recently, with the staff seeing an urgent need to restrain real primary spending. Pension reform was well advanced, and the remaining excessive recourse to early retirement set to be tackled in early 2005 . $^{3}$ There was consensus, including among social partners, for raising employment rates, but staff felt that the wage-bargaining model in its present form was likely to impede progress.

\section{A. Fiscal Policy}

9. Since the mid-1990s, fiscal consolidation efforts have yielded impressive results, but recently, the underlying effort has been relaxed. Public debt fell from a peak of nearly 140 percent of GDP to less than 100 percent of GDP in 2004, and the authorities are committed to reducing this ratio to less than the euro area average within the next ten years (Figure 5 and Tables 2 and 3). This approach is an important pillar of the strategy to deal with aging, whose sustainability depends on utilizing the room from the declining interest bill for aging-related outlays. However, during 2002-04, the primary surplus fell by about 1 percentage point of GDP, as interest savings were applied to tax cuts and increases in primary spending, including on health care and law and order.

\section{The authorities saw continued balanced budgets or small surpluses as essential} for the credibility of their fiscal strategy, even if that implied further recourse to one-off measures. They noted that, following five years of success, deficits had become unacceptable to the public. They agreed with the staff that maintaining this performance during the downswing had required well-designed one-off measures to avoid a contractionary fiscal impulse, which had masked the underlying operation of automatic stabilizers (Text Table 2). With the upswing progressing, one-offs were being phased out, though the authorities considered that they would still be needed to balance the 2005 budget.

\footnotetext{
${ }^{3}$ The main pay-as-you-go pension system is indexed to prices rather than wages, based on a contribution period of 45 years, with pensions calculated on lifetime earnings and capped in absolute amount $(€ 18,040$ per year in 2003). Voluntary second and third pillars are in place.
} 
Text Table 2. Belgium: Budget Balance Adjusted for Cycle and Nonstructural Items (In percent of GDP)

\begin{tabular}{lrrrrrrr}
\hline & 1999 & 2000 & 2001 & 2002 & 2003 & 2004 & 2005 \\
\hline Headline balance & -0.4 & 0.2 & 0.6 & 0.1 & 0.4 & 0.0 & -0.4 \\
Effect of the cycle (-) & 0.6 & 1.8 & 1.1 & 0.1 & -0.6 & -0.4 & -0.3 \\
Nonstructural measures (-) 1/ & -0.1 & -0.2 & 0.4 & 0.2 & 1.5 & 0.7 & 0.4 \\
$\quad$ Of which: Belgacom & & & & & 1.9 & & \\
$\quad$ Of which: Tax amnesty & & & & & & 0.1 & \\
Adjusted structural balance & -0.9 & -1.4 & -0.9 & -0.3 & -0.6 & -0.3 & -0.4 \\
Interest payments (+) & 7.0 & 6.8 & 6.6 & 6.0 & 5.4 & 4.8 & 4.7 \\
Adjusted Structural Primary Balance & 6.1 & 5.4 & 5.7 & 5.7 & 4.9 & 4.4 & 4.2 \\
Memorandum items & & & & & & & \\
Real primary expenditure growth & 3.1 & 2.5 & 1.3 & 4.4 & 4.3 & 1.0 & 3.0 \\
Public debt & 114.4 & 109.2 & 108.0 & 105.4 & 99.9 & 95.9 & 94.9 \\
\hline
\end{tabular}

Sources: BNB; and Fund staff calculations.

$1 /$ Nonstructural measures pertain to the sale of land and property, the receipts from the UMTS auctions (2001), the takeover of the Belgacom pension fund (2003), the tax amnesty (2004), the securitization of tax arrears, timing shifts in the tax collection and the payments to the railways, and various smaller items.

\section{The staff observed that balancing the budget after 2004 would become} increasingly difficult unless durable spending restraint was put in place. Even in 2004, despite strong growth, the overruns on health care spending and the lower-than-expected yield of the tax amnesty had required the preparation of last-minute one-off measures to balance the books (though not all of them had to be implemented in the end, mainly owing to stronger-than-expected corporate tax revenues). For 2005, corrective measures on health care would lower the projected deficit, but in the staff's view, additional measures of about 0.4 percentage point of GDP were needed to achieve balance (Table 4, Scenario A). ${ }^{4}$ In 2006 , reaching balance was likely to be an uphill struggle as the already-adopted tax reform will reduce revenues by about 0.5 percentage point of GDP; moreover, municipal elections were likely to heighten spending pressure, a point acknowledged by the authorities.

\section{The authorities noted that durable spending curbs were being implemented in a}

number of areas. On health care, the early detection of budget overruns had activated existing clawback mechanisms and prompted a number of remedial measures. The staff welcomed this approach, but noted that during this government's term, the health care sector would need to be prepared to return to real spending growth rates lower than the 4.5 percent norm agreed for 2004-07. The authorities observed that one regional government had suspended net replacement of retirees, a practice that the staff suggested could usefully be extended to other parts of the public sector in conjunction with the adoption of information technology. There was, however, little support for staff recommendations to narrow the

\footnotetext{
${ }^{4}$ The staff projects a deficit of 0.4 percent in 2005 , owing to lower estimates of the impact of withholding tax on savings and measures in health care, lower GDP growth, higher unemployment, and higher short-term interest rates.
} 
coverage of entitlements or streamline the many active labor market policies in the context of reforms to raise employment rates.

13. There was consensus among authorities, social partners, and staff that long-term fiscal sustainability required the buildup of budget surpluses and higher labor utilization. Indeed, the authorities' objectives - surpluses of 0.3 percent of GDP by 2007 (Table 4, Scenario B) and 1.5 percent of GDP by 2011, the latter explicitly endorsed by the federal parliament - appeared to be sufficient to set public finances on a sustainable path. The staff emphasized that effecting the required degree of consolidation solely through higher labor utilization, even if done without recourse to budgetary resources, appeared unrealistic, as it would require employment rates of persons aged 20-59 of about 95 percent compared to 73 percent at present. However, consolidating without raising employment necessitated a virtual freeze in discretionary spending - an unattractive option, if at all feasible. It was agreed that an intermediate scenario, combining fiscal adjustment and substantial labor market reform, was the preferred option (Table 4, Scenario C and Box 3). To illustrate, staff noted that curbing discretionary spending growth to about 1.4 percent per year for the next decade and raising the effective employment rate by 10 points by 2030 would secure fiscal sustainability while not requiring a buildup of public assets. As recommended by the staff, further labor and product market reforms would ease this constraint and could also create room for growth-enhancing tax cuts, provided expenditure restraint is in place.

14. To secure realization of these long-term fiscal objectives, the staff called for the adoption of a multiyear expenditure-based fiscal framework. While acknowledging that the focus on, and achievement of, annual nominal budget targets had helped establish credibility and internal fiscal discipline, the staff stressed that, as a result, insufficient attention had been paid to durable spending reform. The associated pursuit of one-off measures had masked the underlying fiscal position, often trading off current benefits for future outlays (such as with the 2003 transfer to the state of Belgacom's pension fund assets and its accompanying liabilities). In contrast, given a medium-term nominal budget target, a multiyear primary expenditure-based framework would have none of these drawbacks, facilitate the political economy of achieving and sustaining surpluses, and support the economy through transparent operation of automatic stabilizers. The authorities acknowledged these points but felt that they did not in the near term outweigh the benefits of adhering to annual nominal budget targets, which would be continued during the current government's term through 2007. Nonetheless, they noted that awareness was building of the merits of shifting to an expenditure-based framework.

\section{There was agreement that an effective internal stability pact was key to securing} fiscal consolidation at all levels of government. The High Finance Council's (HFC) recommendation that all regional authorities converge to a balanced budget by 2010 seemed broadly appropriate. With the federal government in charge of social security and most interest spending, its budget would reflect and accommodate the strategy to cope with aging. Nonetheless, decisions at the regional level can affect federal government spending and, while regions with budget surpluses would have no difficulty in complying with the HFC 


\section{Box 3. Belgium: Coping with Population Aging ${ }^{1}$}

Without remedial policies, population aging will wreak havoc on the fiscal position (see Figure, Current Policies). Between now and 2050, the old-age dependency ratio-defined as those aged over 60 as a share of those between 20-59-is projected to rise from about 40 percent to almost 70 percent and the associated annual fiscal costs by about 7 percentage points of GDP.

In 2002, the High Finance Council proposed a viable fiscal strategy to cope with the costs of aging: steady up-front fiscal adjustment would permit these costs to be fully offset by savings on interest payments, provided the effective employment rate increased by about 5 percentage points. However, since then, the costs of aging have been revised upward, and the pace of fiscal adjustment has fallen behind. In addition, labor market policies are yet to deliver this higher employment.

\section{An effective strategy to address the costs of aging requires both fiscal adjustment and} higher employment rates. To illustrate, suppose these costs would need to be covered solely through fiscal adjustment. With aging costs exceeding the interest bill, generating sufficient savings would mechanically require the buildup of a net asset position by 2050 (Fiscal Adjustment Scenario). In turn, this would necessitate limiting real discretionary primary spending growth to 0.3 percent in each of the next ten years and achieving a fiscal surplus of 4 percent of GDP by 2015 . However, if employment rates were substantially raised, higher growth would facilitate fiscal consolidation, and the lower dependency ratio would reduce the cost of aging. For example, an increase in the employment rate by 10 percentage points between now and 2030 would no longer involve a net asset position in the long run, and fiscal sustainability could be achieved by holding real discretionary primary spending growth to not more than 1.4 percent per year in the next ten years (Adjustment + Reform Scenario). Under such a scenario, a fiscal surplus of about 2 percent in 2015 would suffice.
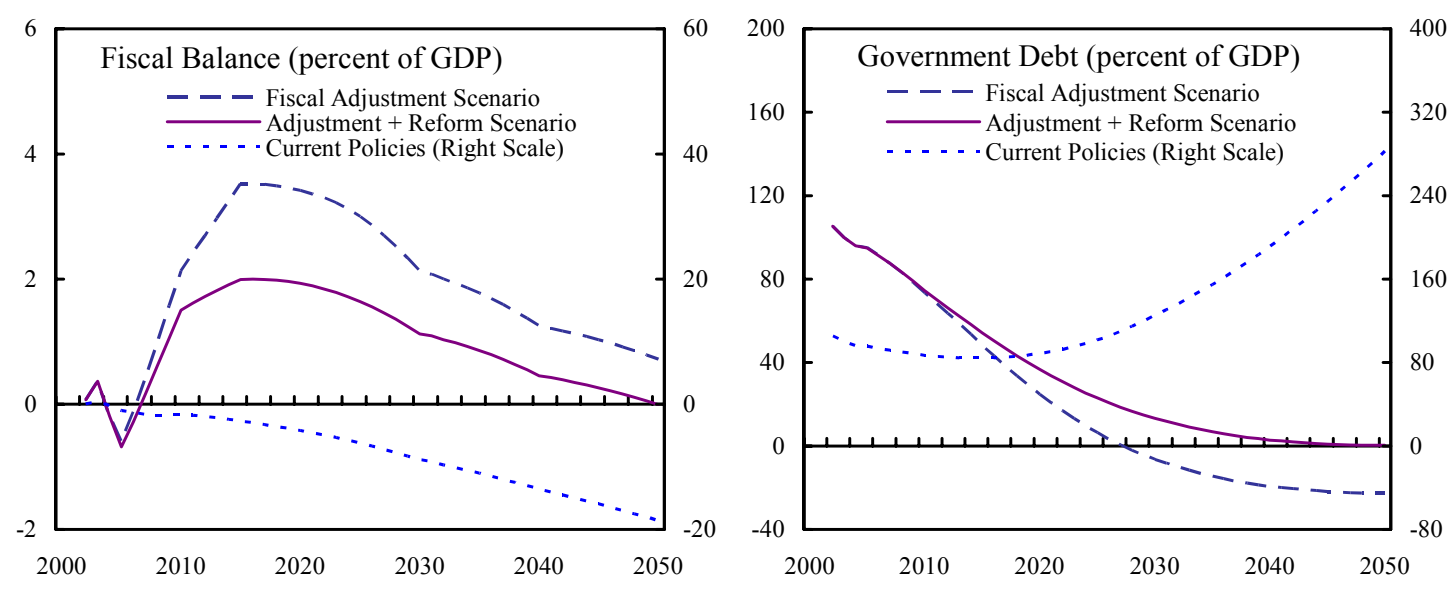

1/ See forthcoming Selected Issues chapter: "Coping with Population Aging in Belgium: An Update." 
recommendations, it was less obvious that regions with deficits would do so. The authorities were therefore receptive to staff suggestions to strengthen monitoring, advance warning procedures, and compliance with the internal stability pact.

\section{B. Labor Market}

16. Raising the low labor utilization is seen as necessary to cope with aging. Indeed, increasing the employment rate by five points (HFC projection) or even ten points (staff recommendation) seems quite feasible, in particular as the causes of low formal employment are well understood (Figures 6 and 7). Social partners and authorities attribute it to the wide tax wedge on labor, generous early retirement schemes, poor career opportunities for older workers, skill mismatches for the young, and region-specific issues (concentration of migrants and hysteresis following industrial restructuring). Rules affecting hiring and firing seem to play a much lesser role (Figure 8 ). While agreeing with these observations, staff pointed to large and open-ended benefits and the wage-bargaining framework as key underlying factors.

\section{Bargaining between social partners governs labor relations and institutions, but} the authorities stand ready to intervene to foster reform. Labor unions, which are also administrators of unemployment and health care benefits and closely affiliated with political parties, have typically come out ahead in the process. With the lump-of-labor paradigm anchoring thinking, labor supply has been curtailed, leading to high labor costs and very capital-intensive production. However, developments in neighboring countries, globalization, the Lisbon process, and pedagogic work by national agencies (e.g., the High Labor Council) have fostered acceptance of the need for labor market reform to raise employment rates. Recognizing that bargaining between social partners may not yield timely results, the authorities have adopted a more proactive approach. They are inviting social partners to negotiate on the basis of a set of government-proposed reforms, with the understanding that failure to agree by a predetermined deadline will lead to imposition of reforms.

\section{There is not only a strong consensus that labor market reforms should not} increase poverty, but also an equity-inspired push to curtail abuse of the welfare system and remove policy-induced inactivity traps. Measures have focused on active labor market policies and structural cuts in social security contributions and income taxes, but with current labor market institutions, the effectiveness of these actions is limited and their budgetary cost high (Box 4). Reducing the level and duration of benefits, or increasing their taxationpolicies advocated by the staff - remain out of bounds; though, with benefits indexed to prices, replacement rates are slowly drifting downward. Job search assistance has been increased for all new unemployed and will be raised for the existing stock of unemployed in the context of a gradual screening for compliance with job search requirements. Initial results of such screenings have been positive. The age for exemption from job search requirements was raised from 55 to 58 . Inactivity traps are being reduced substantially through targeted cuts in social security contributions and child care costs; the earned-income tax credit ("work bonus"); and subsidies for domestic and household services. The High Labor Council is 


\section{Box 4. Belgium: Labor Market Institutions Impede the Effectiveness of Tax Cuts in Raising Employment ${ }^{1 /}$}

Since the early 1980 s, reducing the tax wedge on labor has been an important component of the authorities' strategy to reverse the decline in employment rates. Social security contributions were lowered several times, as were income taxes, most recently in the ongoing multiyear tax reform (the full effect of which will be felt in 2007). Budget constraints limited progress, however, even inducing reversals such as in 1993 when taxes were raised. Tax reductions were often targeted at low-income earners. These cuts, to the extent that they reduce labor costs, stimulate labor demand. They promote labor supply directly and probably also indirectly as net take-home pay rises compared to social benefits. Given empirical evidence that the rise in the labor tax wedge from 38 percent in 1960 to 51 percent in 2000 may have lowered the employment rate by up to 4 percentage points, such a strategy makes sense.

With concurrent fiscal consolidation needs, a tax cut strategy runs into budget constraints. Assuming an employment elasticity with respect to labor costs of 0.5 (common in the literature), increasing employment by 10 percent (consistent with Lisbon targets) requires a 20 percent cut in labor costs, which, if to be achieved through tax cuts only, implies a reduction in taxation to U.S. levels. However, since taxes bite at the margin, basebroadening at lower marginal rates, which is part of the authorities' approach, is helpful. On the other hand, a shift from direct to indirect taxation would be less useful as consumption taxes are part of the labor tax wedge for those who work. In any case, the practice of indexing wages renders such a shift ineffective, except for taxes on products excluded from the index, such as tobacco and energy, which have indeed been rising substantially.

More important, labor market institutions impede an effective tax cut strategy. The strong bargaining position of labor unions implies that reductions in social security contributions and income taxes end up mostly in take-home pay. Staff estimates suggest that the ongoing tax reform (at a budgetary cost of 2 percentage points of GDP) will raise the employment rate by 1.6 percentage points by 2005 . By comparison, if union bargaining power were reduced by half, the employment effect would be 2.2 percentage points, while a fully competitive market would deliver 4.3 percentage points.

\begin{tabular}{lrr}
\multicolumn{2}{c}{ Employment Effects of Labor Tax Cuts in a Wage-Bargaining Model } \\
\hline Changes in marginal effective labor income tax 1/ & $1985-91$ & $2000-05$ \\
\hline Changes in average effective labor income tax 1/ & -3.6 & -3.2 \\
Income tax & -1.6 & 2.0 \\
Employers' SSC & -2.9 & 1.8 \\
Employees' SSC & 2.0 & 0.3 \\
Employment effect under the calibrated wage bargaining model 2/ & -0.7 & -0.1 \\
Employment effect with the bargaining power reduced by half 2/ & 1.8 & 1.6 \\
Actual employment changes 2/ & 2.4 & 2.2 \\
\hline
\end{tabular}

Source: Fund staff estimates.

$1 /$ In percentage points.

2/ Percent change during the period.

\footnotetext{
${ }^{1 /}$ This box draws on the forthcoming Selected Issues chapter "Employment Effects of Reductions in Labor Taxes in a Wage Bargaining Model."
} 
preparing a 2005 update of its assessment of inactivity traps taking into account the recent tax reform.

\section{At the time of the mission, the 2005-06 wage-bargaining round remained} gridlocked, casting doubt on whether it would contribute to rapid increases in employment rates. Employers had been calling for a wage freeze and more flexible work arrangements, while unions had been demanding somewhat more than full price indexation and offering few concessions. As unit labor costs were likely to continue to outpace those in main trading partners, and employment rates were still lagging, the staff argued that there was little or no room for increases in gross nominal wages (see Text Table 3). This position was seen as reasonable by most interlocutors, since cuts in income taxes and increases in the work bonus would still allow net take-home pay to rise. However, labor unions felt that they needed assurances that wage moderation would lead to increased hiring and not just higher profits. In the event, the agreement reached after the mission allows for cumulative nominal wage increases of 4.5 percent during 2005-06. It was also agreed to introduce more flexibility in the use of overtime and shiftwork and make them fiscally more attractive.

Text Table 3. Belgium: Interprofessional Wage Agreements, 1997-2006

(Hourly labor costs, percent change)

\begin{tabular}{|c|c|c|c|c|c|}
\hline & \multirow[t]{2}{*}{$1997-98$} & \multirow[t]{2}{*}{ 1999-2000 } & \multirow[t]{2}{*}{ 2001-02 } & \multirow{2}{*}{$\frac{2003-04}{\text { Estimated }}$} & \multirow{2}{*}{$\begin{array}{r}2005-06 \\
\text { Projected }\end{array}$} \\
\hline & & & & & \\
\hline Labor cost norm $1 /$ & 5.8 & 5.9 & 6.1 & 5.4 & 5.3 \\
\hline Projected inflation (health index) & 3.6 & 3.1 & 3.0 & 2.9 & 3.3 \\
\hline \multicolumn{6}{|l|}{ Actual change } \\
\hline Reference countries & 3.5 & 5.4 & 6.7 & 4.5 & $\ldots$ \\
\hline Belgium & 3.4 & 5.3 & 7.5 & 5.9 & 4.5 \\
\hline \multicolumn{6}{|l|}{ Due to: } \\
\hline Conventional wage increase & 3.6 & 4.4 & 7.1 & 4.2 & 3.6 \\
\hline Indexation & 3.1 & 2.6 & 4.8 & 2.8 & 3.3 \\
\hline Real increase & 0.5 & 1.7 & 2.1 & 1.4 & 0.3 \\
\hline Employers' social security contributions & 0.6 & -1.5 & 1.0 & -0.6 & -0.4 \\
\hline Wage drift & -0.8 & 2.4 & -0.5 & 2.2 & 1.3 \\
\hline \multicolumn{6}{|l|}{ Memorandum items: } \\
\hline Relative unit labor cost (Belgium-reference countries) 2/ & 0.7 & 0.3 & 1.8 & 0.3 & $\ldots$ \\
\hline Effect of income tax cuts on disposible income & $\ldots$ & $\ldots$ & 0.1 & 0.5 & 1.0 \\
\hline
\end{tabular}

Sources: Data provided by the authorities; and Fund staff estimates.

1/ Available room for labor cost increases computed as the weighted average of projected changes in the reference countries France, Germany, and the Netherlands.

2/ Data for 2003-04 are for 2003 only.

20. Concerned that the staff-advocated overhaul of the current framework might cost much in terms of social peace and cohesion, the authorities indicated their preference to work within its scope, while accepting the staff's point that this could lead to an ultimately lower degree of labor utilization. While since the inception of the competitiveness law in 1996 wage drift arguably slowed compared to trading partners, it has remained high. Overruns of the labor cost norm, whether due to higher-than-anticipated 
inflation or wage drift, were not corrected in subsequent agreements despite a legal provision permitting such action. In addition, cuts in income taxes and employer and employee social security contributions appear to have translated into higher take-home pay rather than lower labor costs. Moreover, the sectoral, regional, and age-related hourly minimum wages well in excess of the national average minimum wage imply a low effectiveness of budgetary and other measures to address inactivity traps. Finally, wage dispersion is very limited, mainly due to price indexation and administrative extension of sectoral agreements. Based on these points, the staff felt that the current wage bargaining framework would not be able to deliver significantly higher employment rates.

\section{The authorities' immediate priority is to modify the early retirement regime to} prevent premature exit from the labor force. They have proposed to social partners a broad menu of measures aimed at improving the career prospects, labor market availability, and flexibility of working arrangements for older workers. The menu includes financial disincentives for employers and employees seeking use of the early retirement regime. Reflecting labor union demands, early retirement has remained an option in the case of enterprise restructuring, but as a last rather than first resort. Social partners are expected to agree on a set of measures in the spring of 2005, and the government has announced that reforms will be imposed in the absence of agreement. The staff and employers argued for a grandfathered, but complete phasing-out of early retirement schemes and the introduction of actuarial fairness into the retirement decision, which, according to the OECD, could boost the employment rate by 2.3 percentage points.

\section{Product Markets, Financial Sector, and Other Issues}

\section{Product markets are becoming gradually more efficient, supported by a} reduction in the administrative burden on enterprises. The strengthened competition authority, expected to become operational in early 2005, should help competition. This issue is especially relevant in electricity, fixed-line telecommunications, and domestic postal services, where incumbents are still exercising varying degrees of monopoly power. In the electricity sector, the authorities have responded by instituting the cross-border integration of infrastructure and markets, which will, however, take a few years to materialize. Railway reforms are proceeding in line with EU directives. The staff urged the authorities to seek efficiency gains in exchange for the takeover of old railway debt. All price notification requirements and the symbolic control over the basic bread price were abolished in 2004 . A one-stop shop for starting a business has been established, and corporate identification numbers are being unified across different administrations. The staff encouraged the authorities to reduce the fragmentation of the responsibility for simplifying procedures.

\section{Supported by the economic recovery, financial sector performance improved} in 2004, while markets developed in new directions. Bank profitability increased substantially, and the insurance sector sustained its return to profit, mainly due to increased premiums in the nonlife segment and higher equity valuations (Table 5). Nonetheless, banks' operating costs remain high because restructuring is proceeding gradually. Life insurance continues to suffer from the low interest-rate environment, since many of its guaranteed- 
return policies are locked in at above-market interest rates, while the recent shift toward fixed income securities on the asset side makes the sector's solvency margin vulnerable to increases in interest rates. Bank lending to households, including mortgages, exceeded lending to the corporate sector, as large corporate borrowers turned to capital markets for funding. Smaller enterprises saw loan supply restricted, reportedly in the context of banks' preparations for Basel II. Bank exposure to corporate borrowers from Central and Eastern European countries increased, while foreign currency exposure remained fully hedged.

\section{A consolidated financial supervisory agency covering banking, finance, and} insurance started operating at the beginning of 2004, and the central bank continues to strengthen macroprudential supervision. The new agency is expected to facilitate and improve supervision of the sector, which is dominated by four banking-insurance conglomerates. The FSAP forthcoming with the next Article IV consultation will provide a timely assessment of any remaining issues. ${ }^{5}$ The central bank's regular publication of financial stability reviews is helping market participants and fostering market discipline.

25. The authorities continue to support multilateral trade liberalization. The 2003 reform of the EU Common Agricultural Policy became effective in Belgium on January 1, 2005. The effects of EU enlargement have been largely anticipated. The authorities are availing themselves of the moratorium on immigration from newly acceded countries and are not considering an active migration policy to attenuate the consequences of aging. Belgium continues to update its framework to combat money laundering and financing of terrorism. The conclusions and recommendations of the FATF's assessment conducted in January 2005 will be included in the forthcoming FSAP. The legal system is in compliance with the OECD antibribery convention, and the UN convention against corruption is expected to be ratified by parliament in 2005 . Official development assistance increased by 40 percent in 2003 to 0.6 percent of GNI, reflecting the commitment to reach the UN target of 0.7 percent of GNI in the near term. Economic statistics are comprehensive and timely. It would be helpful to provide quarterly general government data and increase public availability of key financial sector indicators.

\section{Staff Appraisal}

\section{Belgium's enviable record of good economic performance and low poverty will be} put to the test by impending population aging and increasing global competitive pressures. Policies have made progress in addressing these issues but need to be strengthened on a broad front. Both fiscal adjustment and labor market reforms should be pursued concurrently over the medium term. Fiscal adjustment, as planned, should prefund part of the cost of aging while avoiding future tax increases or cuts in already small pension benefits. Concomitantly, achieving higher employment rates is necessary to raise growth and enable sustained fiscal consolidation, while preserving favorable social outcomes.

\footnotetext{
${ }^{5}$ A first mission took place in December 2004.
} 
27. The economy has been performing remarkably well, propelled by strong household spending and supported by the global recovery and policies. Tax cuts and wage increases have sustained disposable income growth; meanwhile, household savings resumed a declining trend, reflecting an improved economic outlook and confidence in the authorities' fiscal strategy. The growth outlook remains auspicious, but there are several downside risks. Externally, high oil prices, softer demand in major trading partners, and further euro appreciation could stifle growth. Domestically, weaker-than-expected employment or sagging confidence could dampen growth prospects.

\section{Fiscal consolidation goals are appropriate, but substantial fiscal measures will} need to be implemented to achieve them. Against the background of robust economic growth, balancing the budget in 2005 appears feasible, though not without further efforts, especially on health care. Additional fiscal adjustment supported by measures to raise labor utilization should be put in place to meet the authorities' objectives of achieving a small surplus by 2007 and a structural surplus of 1.5 percent of GDP by 2011 .

29. In this context, structural reforms are urgent in key spending areas. In health care, the authorities' early response to spending overruns is commendable, but medium-term reforms are equally necessary to lower health care spending growth. The adoption of information technology and the impending wave of retirements in the civil service should be used for substantial savings. As part of a comprehensive labor market reform, the coverage of entitlements should be narrowed and active labor market programs streamlined.

30. To help achieve fiscal consolidation objectives and spending restraint in the medium term, the focus of fiscal management should shift toward adherence to multiyear primary spending limits. Preparations for such a shift should be completed within the current government's term. This new focus will permit durable spending measures to substitute for the ongoing recourse to one-off measures, for which the scope is rapidly diminishing. In addition, the internal stability pact between the federal and regional governments should be renewed and strengthened to ensure that all regions balance their budgets in the long run and that their decisions do not adversely affect the federal budget.

\section{Boosting labor utilization, a necessary component of the strategy to deal with} population aging, requires a comprehensive approach. Raising employment rates calls for a reduction in the relative cost of labor and an elimination of disincentives to work. In this context, it will be essential to keep wage increases to a minimum and avoid wage drift in 2005-06, especially as ongoing tax reductions will still allow net take-home pay to rise. Beyond the near term, the collective bargaining system should be modified to ensure its effectiveness in delivering higher employment rates. To promote wage dispersion and labor mobility, wage indexation and anomalies such as sectoral, regional, and age-related minimum wages should be abolished, and more flexible work and wage arrangements should be allowed at the enterprise level.

32. Specific policy adjustments are needed to prevent the premature exit of older workers from the labor force. By making the retirement decision actuarially fair across all 
pension schemes and providing regularly full information about its financial consequences, the decision about when to retire should be left to the individual. While proposals to reform early retirement schemes are a decisive step in the right direction, such schemes should best be phased out. Since corporate restructurings are a reality, the challenge of keeping older workers in the labor force calls for accompanying programs, as recognized by the authorities and social partners. In this regard, care should be taken to not create new disincentives for hiring.

33. A number of welcome measures will promote the employment of the low-skilled and the young. The tightening of job search and availability requirements is likely to increase the speed at which people move into new jobs. To buttress this approach, the duration of unemployment benefits should be limited. The earned income tax credit will mitigate inactivity traps; it should be supported by further changes in the tax and benefit system. In addition, the evaluation of the effectiveness of all labor market policies and their streamlining and fine-tuning should be continued.

\section{In product markets, the ongoing progress in liberalizing network sectors and} promoting competition should be extended to all regions and accelerated to ensure that it translates into benefits for the consumer. The change in the corporate structure of the railways, facilitated by the takeover by the state of some of the old debt, is a step forward, but to secure lasting efficiency gains, this should be complemented by a gradual reduction of subsidies. In certain areas, effective competition remains to be introduced, a process that should be helped by the establishment of a new competition authority. Efforts to reduce the administrative burden on enterprises and taxpayers are beginning to pay off, but further progress is necessary to reap the full benefits of available information technology.

35. In the financial sector, banks and nonlife insurance have performed well, but the life insurance sector remains vulnerable to interest-rate developments. The merger of banking and insurance supervisory agencies is progressing apace and should improve supervision of the banking-insurance conglomerates. The regular publication by the central bank of financial stability reviews has contributed to market discipline. The authorities' decision to participate in an FSAP in the context of the next Article IV Consultation is welcome.

36. The ongoing increase in official development assistance and the authorities' commitment to raise it to the UN target are commendable. In this context, the authorities should also use their position in international institutions to promote multilateral trade liberalization.

37. It is proposed that the next Article IV Consultation take place on the standard 12-month cycle. 
Figure 1. Belgium: Economic Developments

(Year-on-year growth rates; unless otherwise indicated)
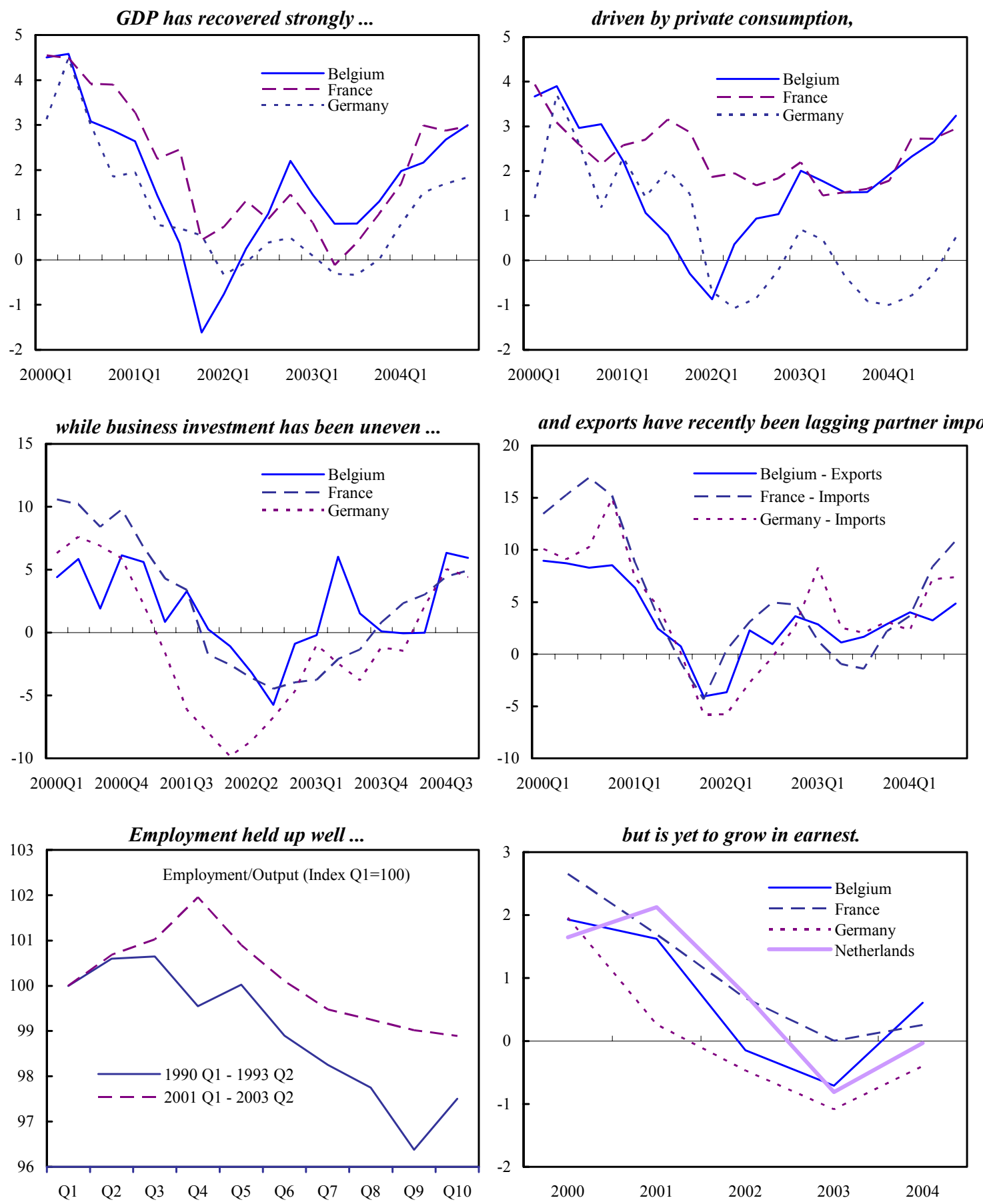

Sources: AMECO; BelgoStat; Eurostat; OECD Economic Outlook; and IMF, WEO. 
Figure 2. Belgium: Inflation and Wage Developments (12-month growth rate)
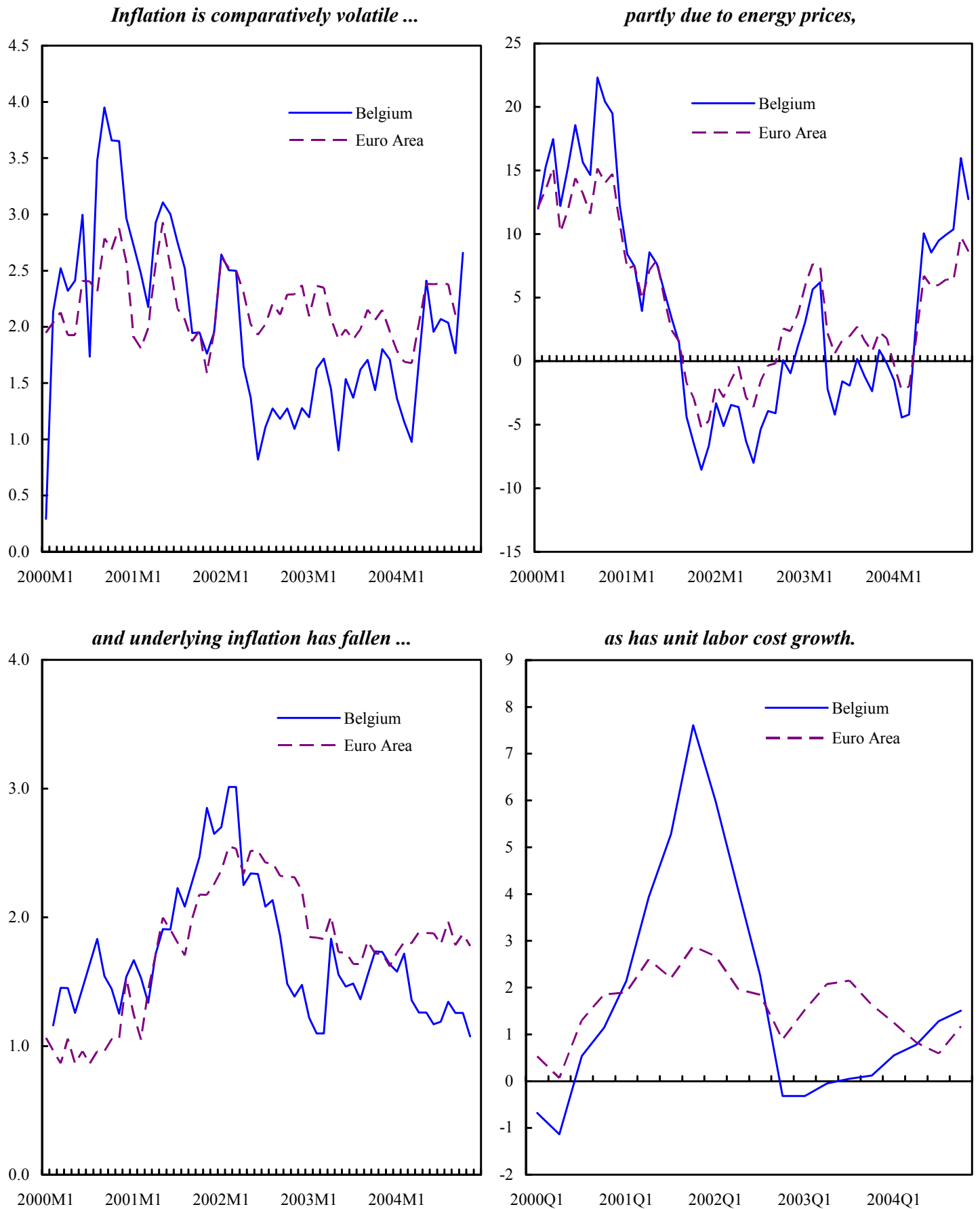

Sources: IMF, IFS; OECD Economic Outlook; and Cronos database. 
Figure 3. Belgium: External Developments
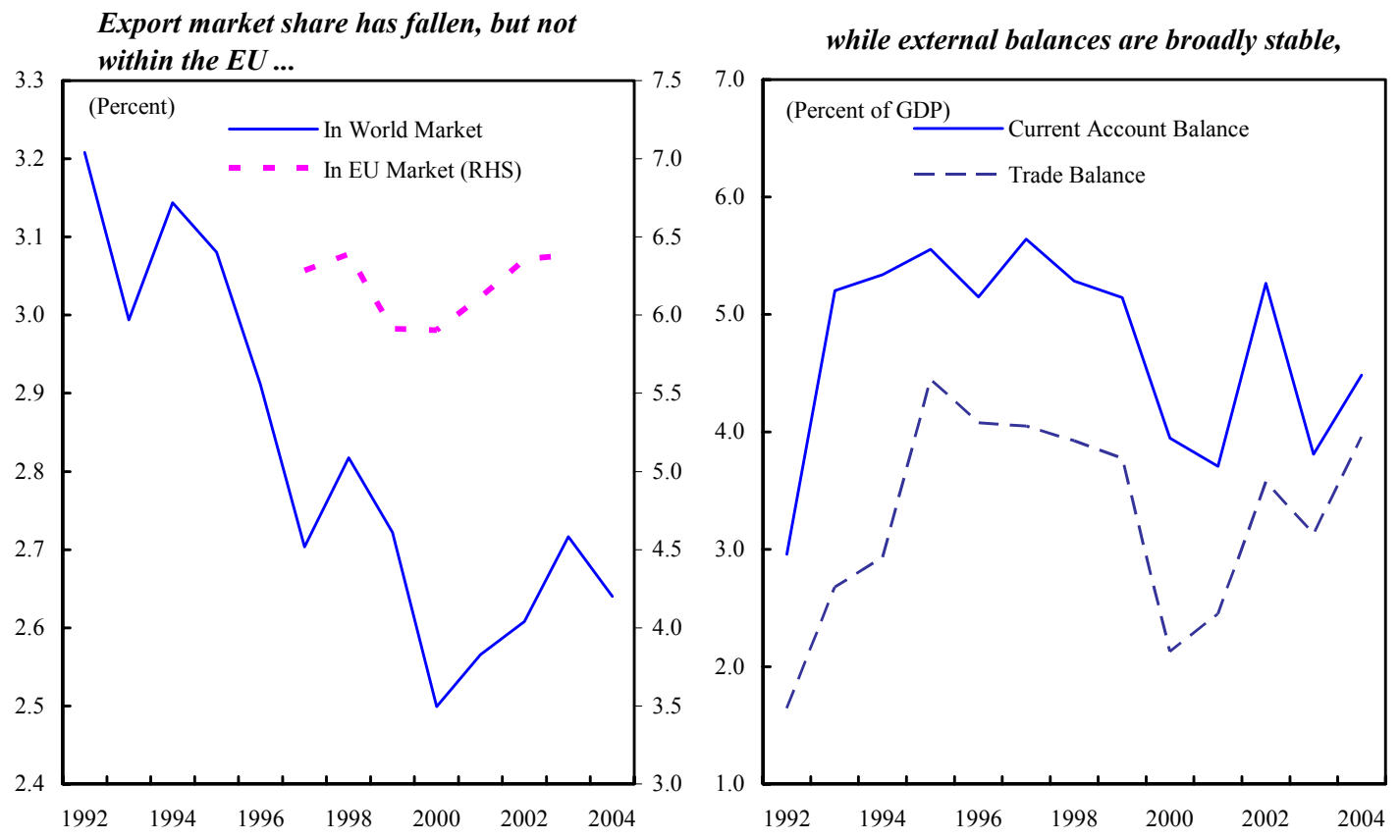

despite real exchange rate appreciation 1/

and average perceptions of competitiveness. 2/
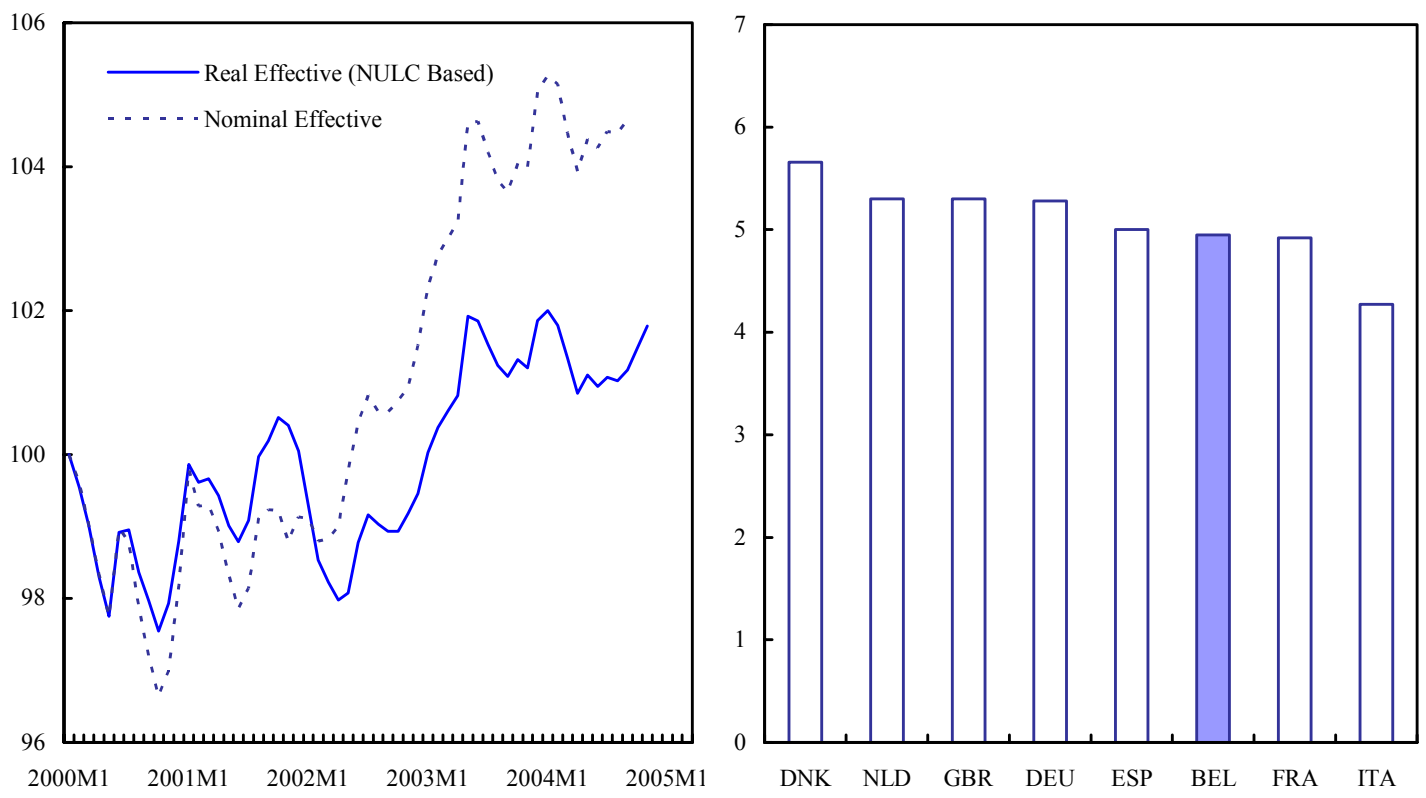

Sources: World Economic Forum Global; and IMF, IFS and WEO.

$1 /$ Index 2000M1 $=100$. An increase indicates an appreciation.

2/ World Economic Forum Global Competiveness index ( $6=$ maximum competitiveness). 
Figure 4. Belgium: Policy Conditions
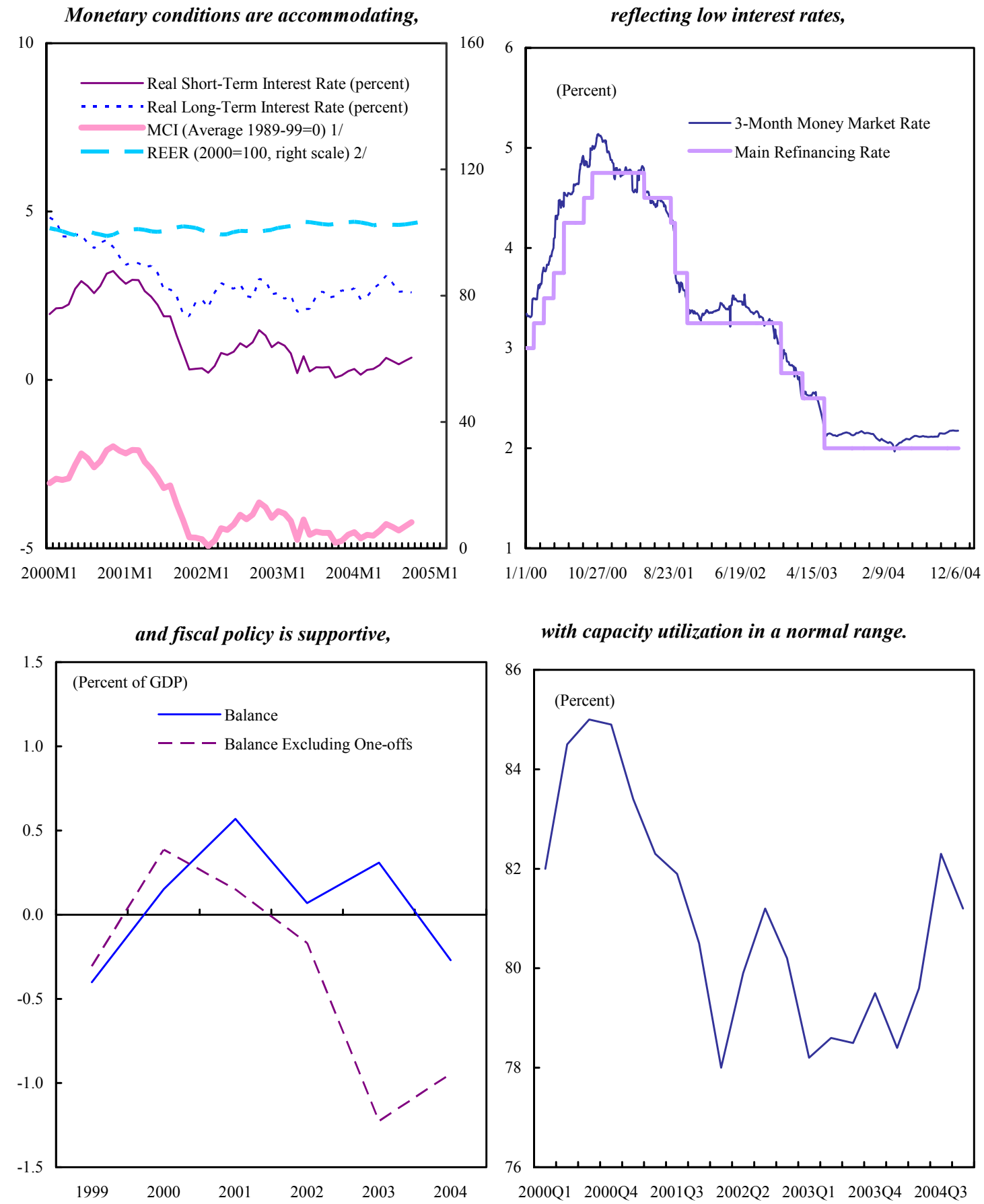

Sources: IMF, IFS; and European Central Bank.

$1 /$ The monetary conditions index (MCI) is a weighted average of the real effective exchange rate (weight $=1 / 11$ ) and the short-term real interest rate (weight=10/11).

$2 /$ Real effective exchange rate index based on normalized unit labor costs. 
Figure 5. Belgium: Fiscal Developments

(In percent of GDP)

Primary surpluses have been built up ...

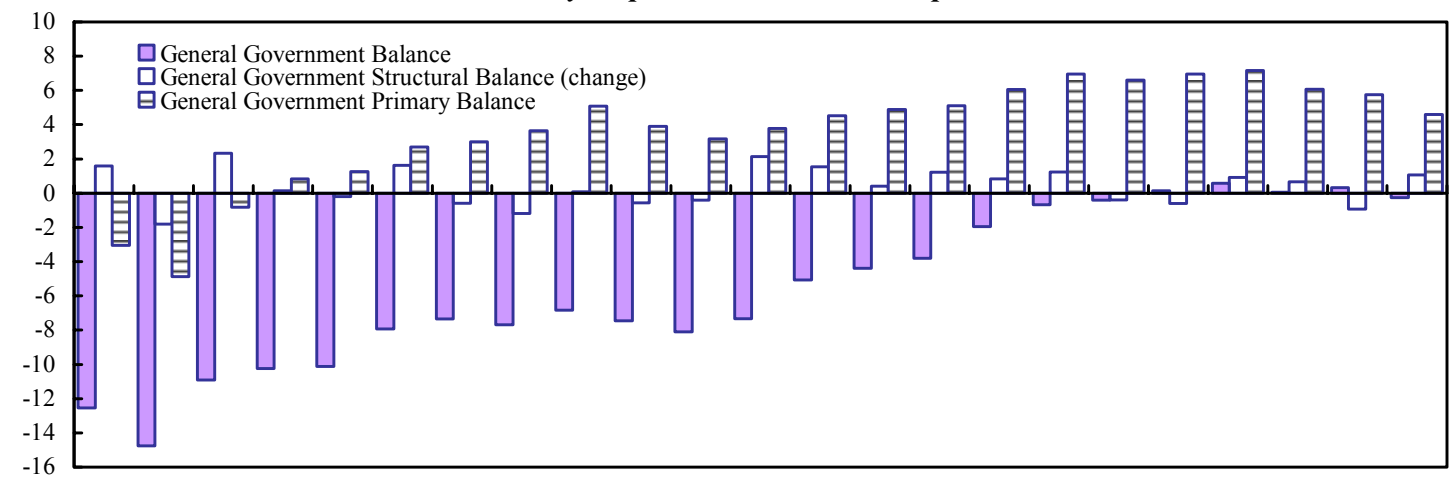

19821983198419851986198719881989199019911992199319941995199619971998199920002001200220032004

reflecting declines in spending and some increases in revenue,

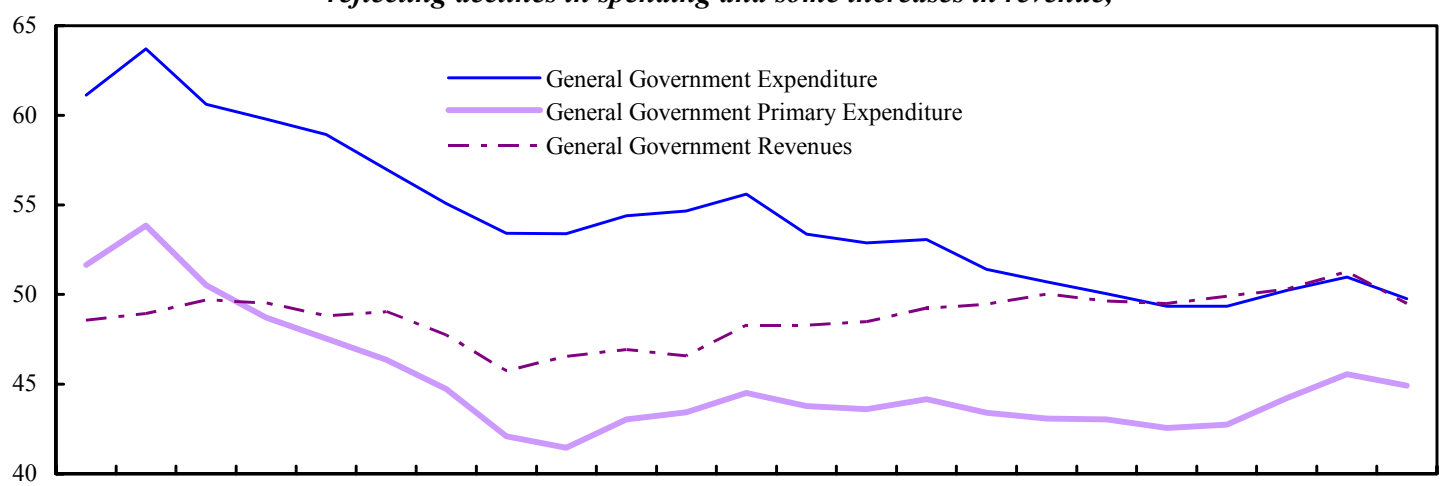

19821983198419851986198719881989199019911992199319941995199619971998199920002001200220032004

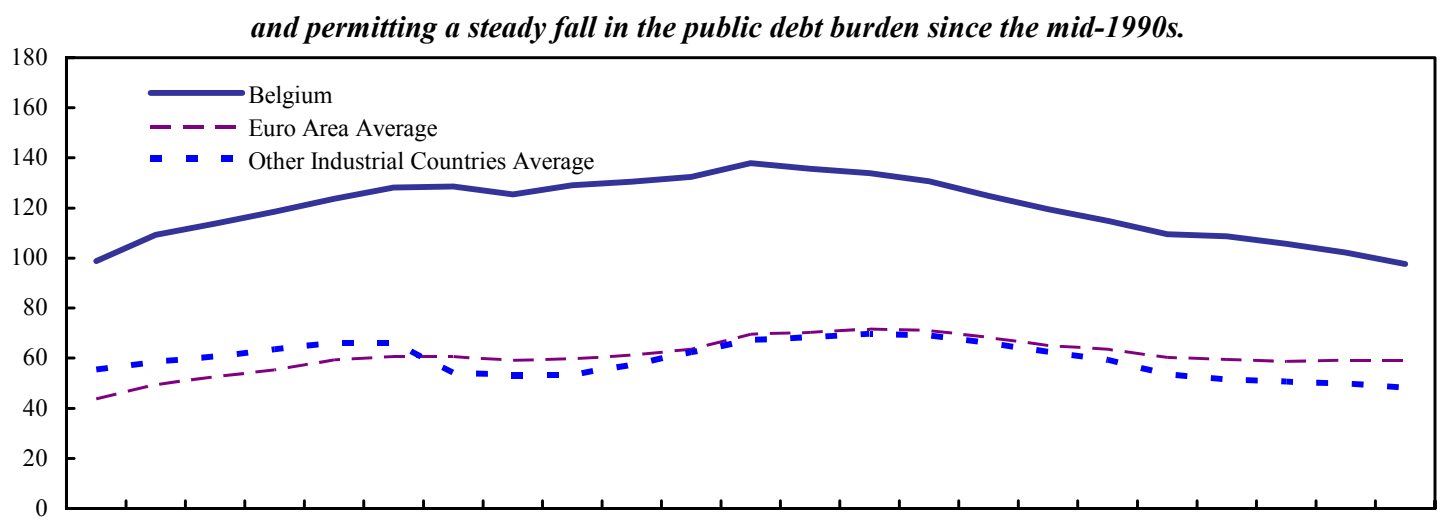

19821983198419851986198719881989199019911992199319941995199619971998199920002001200220032004

Source: IMF, WEO. 
Figure 6. Belgium: Employment and Unemployment

(In percent of the labor force; unless otherwise indicated)

More persons are in jobs,

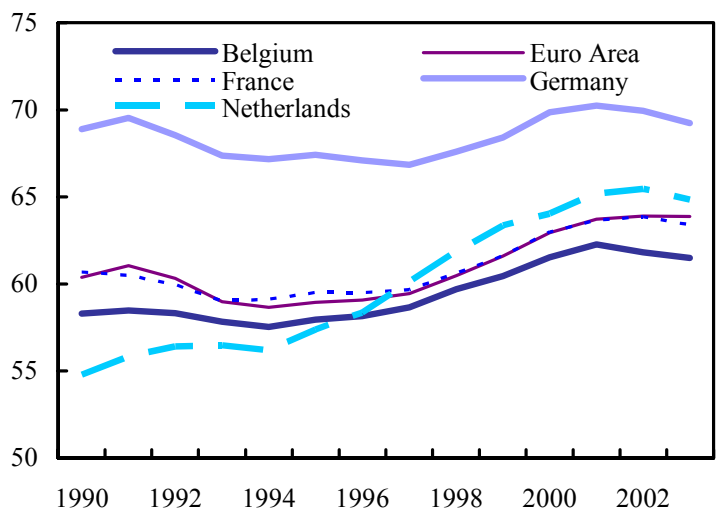

reflecting rising part-time work.

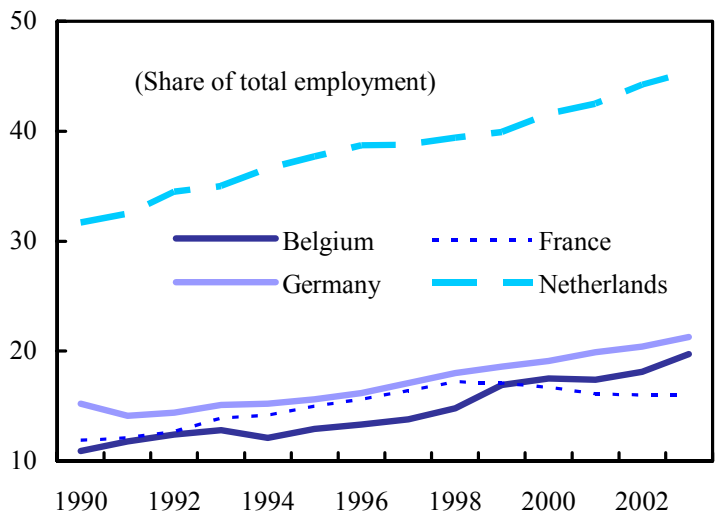

with stark regional differences

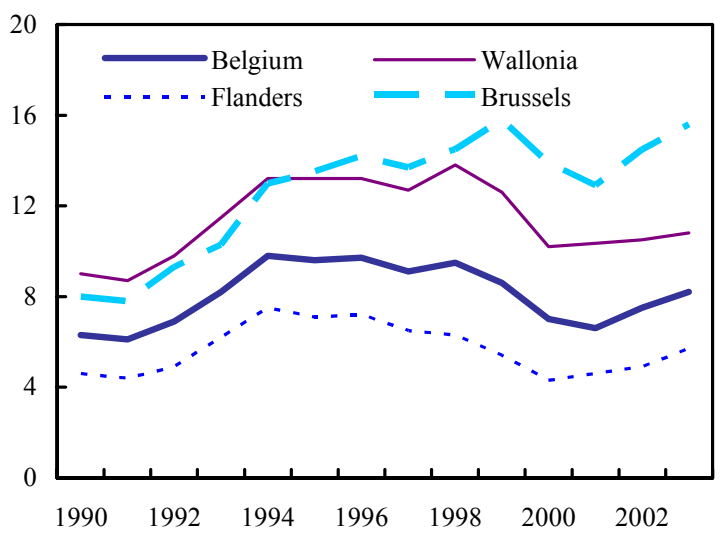

while hours worked are stable,

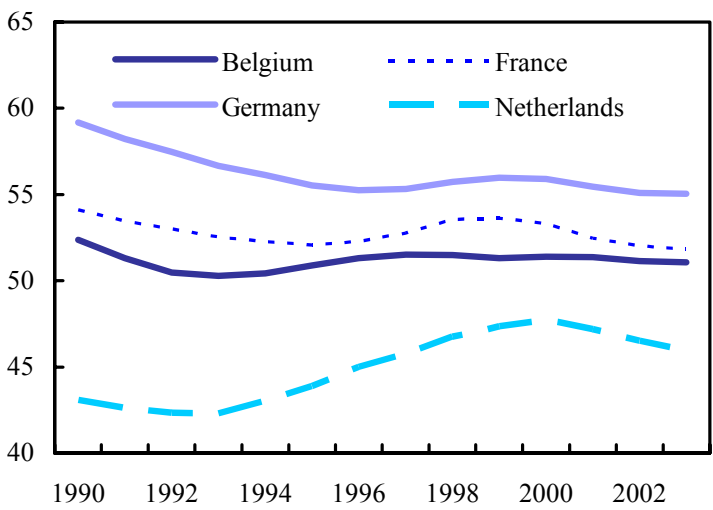

Unemployment remains relatively high,

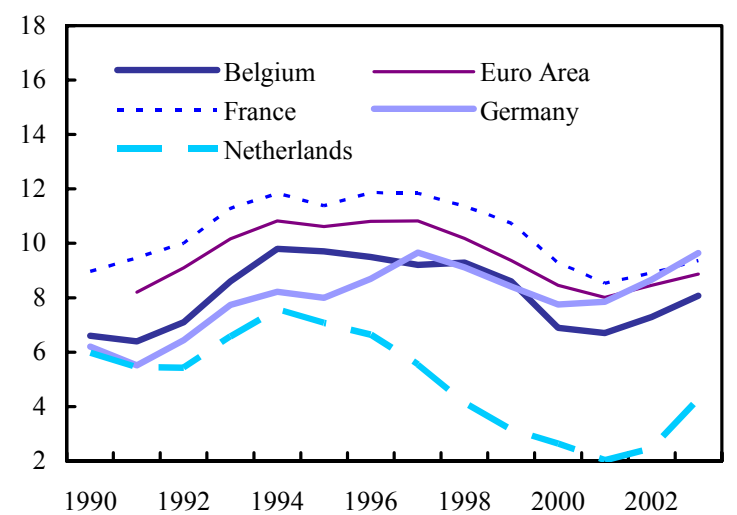

and higher incidence on the young (ages 15-24).

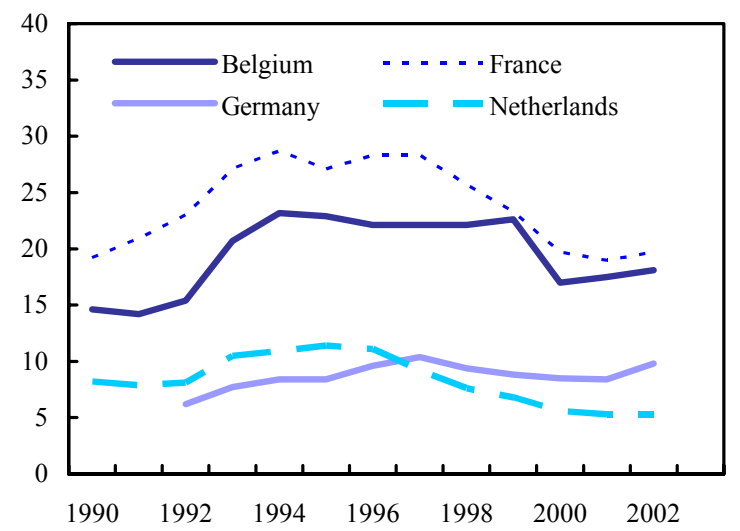

Sources: Data provided by the Belgian authorities; OECD; Cronos Database; IMF, WEO; and Fund staff calculations. 
Figure 7. Belgium: Labor Market Indicators, 2003

Employment is among the lowest, 1/
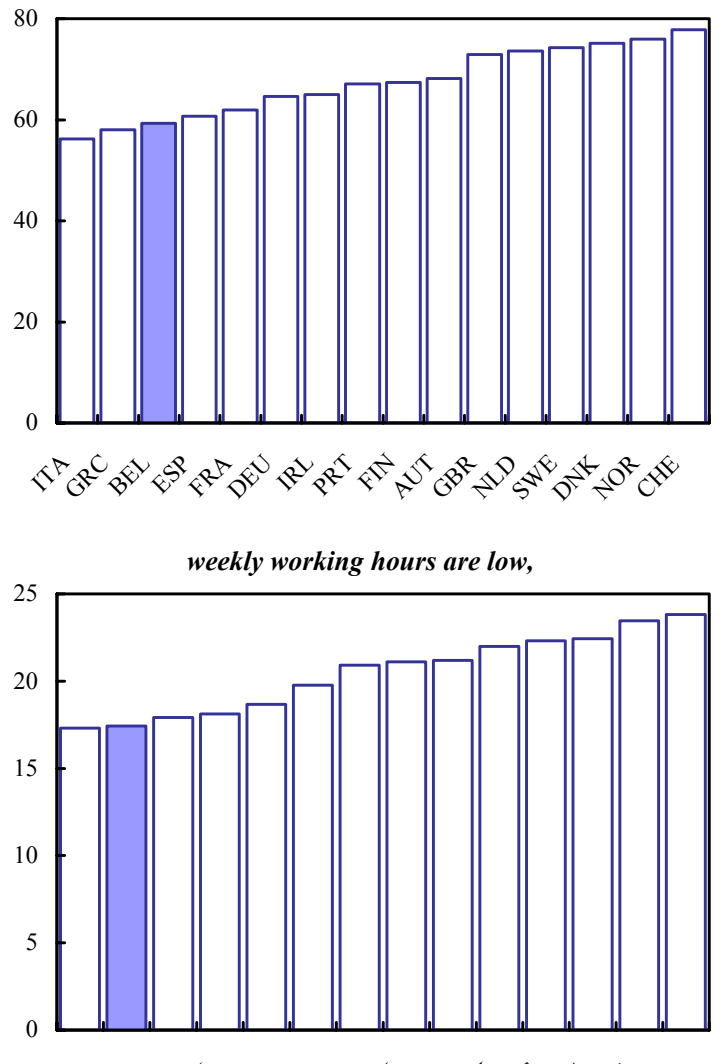

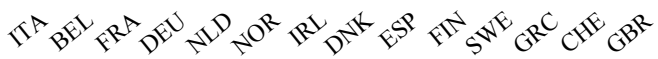

as are labor costs, 4/

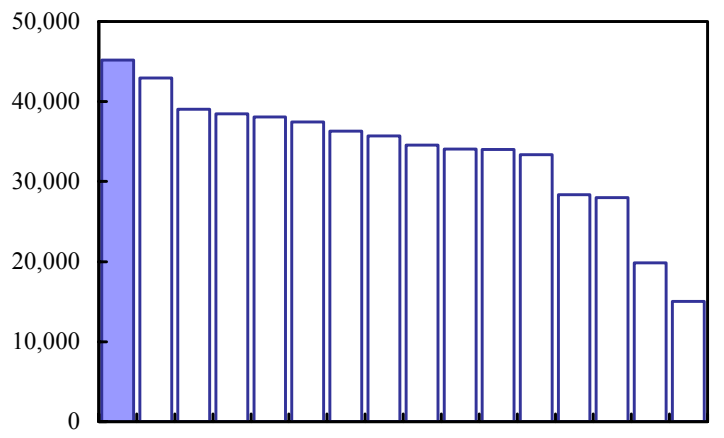

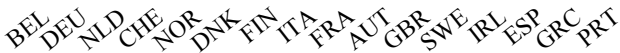

especially for the old, 2/

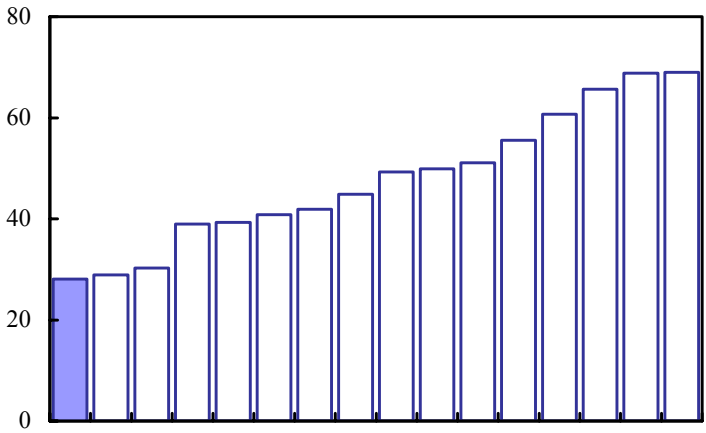

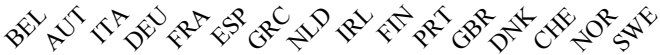

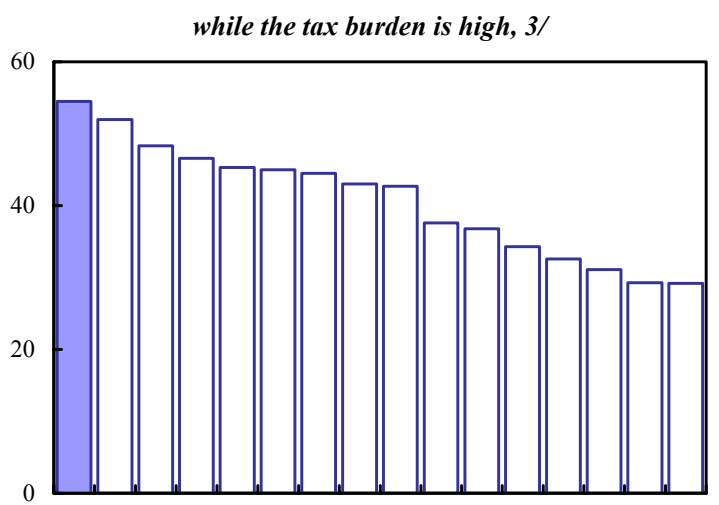

कर्ये

and public spending on labor market programs. 5/

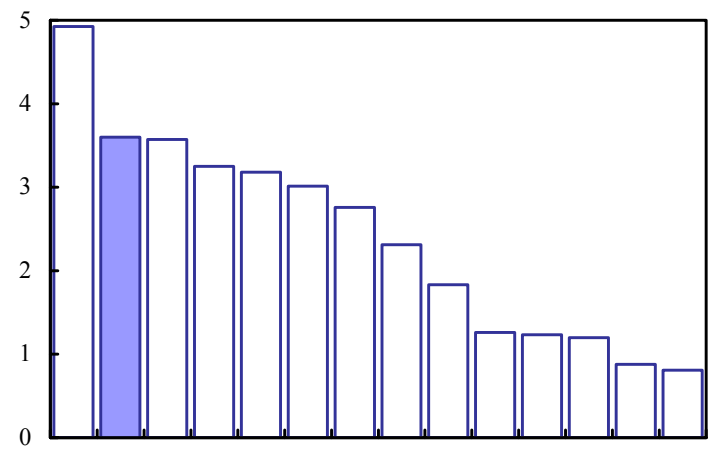

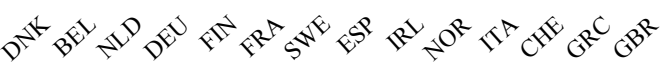

Sources: OECD; and IMF staff estimates.

1 / In percent of population aged 15-64 years.

$2 /$ In percent of population aged 55-64 years.

3/ Income tax plus employee and employer contributions as percent of labor costs (single persons without children).

4/ In dollars, PPP adjusted.

5/ Percent of GDP (1999-2002 average). 
Figure 8. Belgium: Hiring and Firing
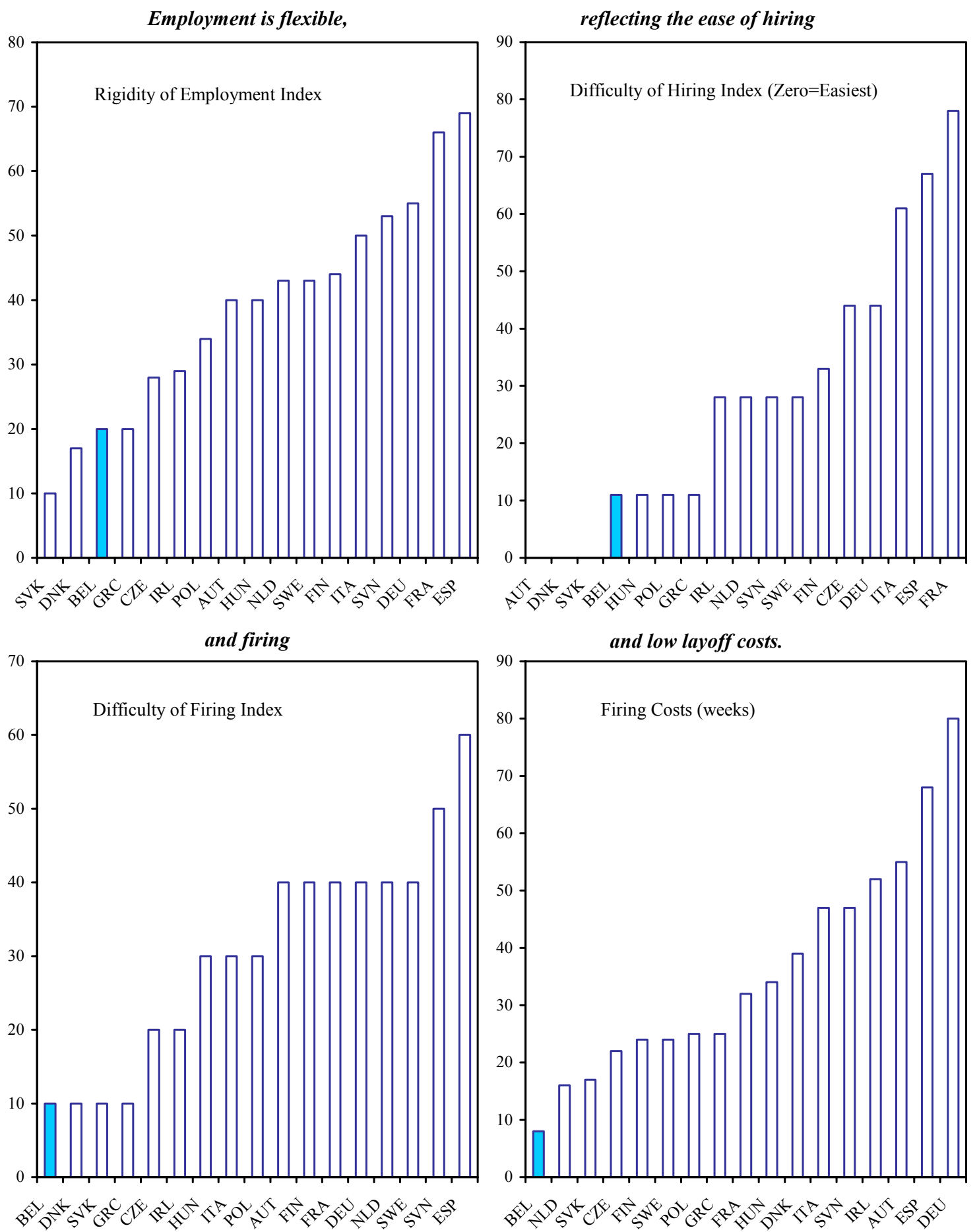

Source: World Bank "Doing Business in 2005". 
Table 1. Belgium: Basic Data, 1999-2005

Demographic and other data:

Population (2003)

GDP per capita (2003)

Social indicators (2003)

Life expectancy at birth

Male

Female

Infant mortality rate

Population per physician (1995)

Population per sq. km. (1995)

\author{
10.3 million \\ $\$ 29,408$ \\ 75.1 \\ 81.1 \\ 5 per 1,000 live births \\ 437 \\ 335
}

Private consumption

Public consumption

Gross capital formation

Exports of goods and services

Imports of goods and services GDP

\begin{tabular}{cc}
\multicolumn{2}{c}{1990} \\
\hline $\begin{array}{cc}\text { Billions } & \text { Percent } \\
\text { of Euros } & \text { of GDP }\end{array}$
\end{tabular}

\section{5}

33.2

36.5

116.1

112.8

163.4

1999
55.4

20.3

22.3

71.1

69.1

100.0

\begin{tabular}{cc}
2003 & \\
\hline $\begin{array}{c}\text { Billions } \\
\text { of Euros }\end{array}$ & $\begin{array}{c}\text { Percent } \\
\text { of GDP }\end{array}$
\end{tabular}

146.9

61.4

51.1

220.0

209.3

269.6

$$
22.8
$$

18.9

81.6

77.6

100.0

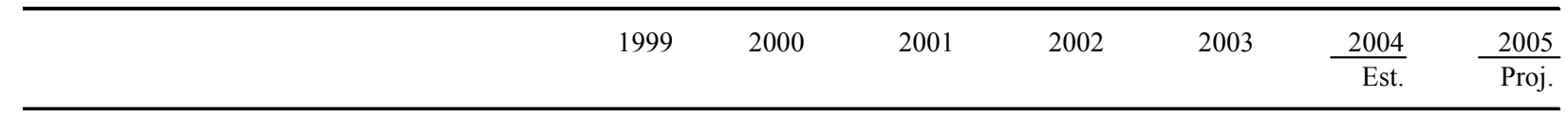

\section{National Accounts}

(Changes in percent)

Demand and output (volume)

Private consumption

Public consumption

Gross fixed investment

Of which: enterprise investment

Stockbuilding 1/

Total domestic demand

Exports of goods and nonfactor services

Imports of goods and nonfactor servises

Foreign balance 1/

GDP

Output gap (in percent of potential GDP)

Manufacturing production

\section{Labor market}

Labor force (national definition)

Employment (national definition)

EU harmonized unemployment rate 2/

NAIRU

Prices, wages, and incomes

GDP deflator

Terms of trade (goods)

Consumer price index 3 /

Compensation per employee 4/

Labor productivity 4/

Unit labor costs 4/

$\begin{array}{rrrrrrr}2.3 & 3.4 & 0.7 & 0.3 & 2.2 & 2.3 & 2.3 \\ 3.5 & 2.3 & 2.7 & 2.3 & 2.7 & 3.5 & 1.6 \\ 4.5 & 3.4 & 0.6 & -3.4 & -0.6 & 2.8 & 4.0 \\ 2.3 & 4.4 & 3.6 & -3.8 & -1.9 & 3.0 & 4.0 \\ -0.5 & 0.5 & -0.9 & 0.7 & -0.1 & 0.4 & -0.2 \\ 2.5 & 3.6 & 0.2 & 0.6 & 1.6 & 3.1 & 2.5 \\ 5.3 & 8.2 & 1.8 & 1.3 & 1.7 & 4.0 & 5.5 \\ 4.5 & 8.3 & 1.0 & 1.0 & 2.1 & 4.5 & 5.6 \\ 0.8 & 0.2 & 0.6 & 0.3 & -0.3 & -0.3 & 0.1 \\ 3.2 & 3.7 & 0.9 & 0.9 & 1.3 & 2.7 & 2.2 \\ 0.0 & 2.6 & 1.2 & -0.1 & -1.0 & -0.5 & -0.4 \\ 1.1 & 4.9 & -0.4 & 1.3 & 0.4 & 3.0 & 2.7 \\ & & & & & & \\ 0.5 & 1.0 & 1.2 & 0.2 & 0.6 & 1.0 & 0.3 \\ 1.3 & 1.9 & 1.5 & -0.3 & 0.1 & 0.7 & 0.4 \\ 8.6 & 6.9 & 6.7 & 7.3 & 7.9 & 7.8 & 7.7 \\ 9.0 & 8.5 & 8.3 & 7.9 & 7.9 & 7.9 & 7.9 \\ & & & & & & \\ 1.4 & 1.3 & 1.8 & 1.8 & 2.0 & 2.0 & 2.2 \\ -0.6 & -1.3 & -1.0 & 1.5 & -0.2 & 0.9 & 0.3 \\ 1.2 & 2.3 & 2.5 & 1.7 & 1.8 & 1.9 & 2.2 \\ 3.9 & 2.6 & 4.1 & 4.3 & 2.1 & 3.3 & 4.6 \\ 1.8 & 1.8 & -0.6 & 1.2 & 1.2 & 2.0 & 1.8 \\ 2.0 & 0.8 & 4.8 & 3.1 & 0.9 & 1.3 & 2.8\end{array}$


Table 1. Belgium: Basic Data, 1999-2005 (concluded)

\begin{tabular}{|c|c|c|c|c|c|c|c|}
\hline & 1999 & 2000 & 2001 & 2002 & 2003 & $\frac{2004}{\text { Est. }}$ & $\frac{2005}{\text { Proj. }}$ \\
\hline & \multicolumn{7}{|c|}{ (In percent) } \\
\hline \multicolumn{8}{|l|}{ Interest rates } \\
\hline Money market rate 5/ & 3.0 & 4.4 & 4.3 & 3.3 & 2.2 & 2.2 & $\ldots$ \\
\hline Government bond yield & 4.7 & 5.6 & 5.1 & 5.0 & 4.2 & 4.3 & $\ldots$ \\
\hline & \multicolumn{7}{|c|}{ (In percent of GDP) } \\
\hline \multicolumn{8}{|l|}{ Saving and investment } \\
\hline Private saving & 26.5 & 25.5 & 24.3 & 24.9 & 23.1 & 23.2 & 23.4 \\
\hline $\begin{array}{l}\text { Of which: household saving as percent of } \\
\text { disposable household income }\end{array}$ & 15.8 & 14.4 & 16.3 & 16.6 & 15.5 & 14.7 & 14.1 \\
\hline Private investment & 19.1 & 19.2 & 19.2 & 17.9 & 17.4 & 17.2 & 17.3 \\
\hline Private saving surplus & 7.4 & 6.3 & 5.1 & 7.0 & 5.8 & 6.0 & 6.0 \\
\hline Government saving surplus & -1.6 & -1.4 & -1.3 & -1.4 & -1.3 & -1.7 & -2.1 \\
\hline National saving surplus & 5.8 & 4.9 & 3.9 & 5.6 & 4.5 & 4.3 & 3.9 \\
\hline \multicolumn{8}{|l|}{ Public finances, general government } \\
\hline Revenue & 49.6 & 49.5 & 49.9 & 50.3 & 51.3 & 49.6 & 49.4 \\
\hline Expenditure & 50.0 & 49.3 & 49.3 & 50.2 & 51.0 & 49.6 & 49.8 \\
\hline Of which: interest on public debt & 7.0 & 6.8 & 6.6 & 6.0 & 5.4 & 4.8 & 4.7 \\
\hline Fiscal balance $6 /$ & -0.4 & 0.2 & 0.6 & 0.1 & 0.4 & 0.0 & -0.4 \\
\hline Primary balance 6/ & 6.6 & 6.9 & 7.2 & 6.1 & 5.8 & 4.8 & 4.3 \\
\hline Structural balance $7 /$ & -1.0 & -1.6 & -0.7 & -0.1 & -0.9 & 0.3 & -0.1 \\
\hline Structural primary balance $7 /$ & 6.0 & 5.3 & 6.0 & 5.9 & 4.5 & 5.1 & 4.6 \\
\hline Gross public debt & 114.4 & 109.2 & 108.0 & 105.4 & 99.9 & 95.9 & 94.9 \\
\hline \multicolumn{8}{|c|}{ (In billions of euros; unless otherwise indicated) } \\
\hline \multicolumn{8}{|l|}{ Balance of payments } \\
\hline Current account balance & 12.1 & 9.8 & 9.4 & 13.7 & 10.3 & 11.0 & 11.5 \\
\hline (In percent of GDP) & 5.1 & 3.9 & 3.7 & 5.3 & 3.8 & 3.9 & 3.9 \\
\hline Trade balance & 8.9 & 5.3 & 6.2 & 9.3 & 8.4 & 9.8 & 10.9 \\
\hline (In percent of GDP) & 3.8 & 2.1 & 2.4 & 3.6 & 3.1 & 3.5 & 3.7 \\
\hline \multicolumn{8}{|l|}{ Exchange rates } \\
\hline Euro per U.S. dollar (December 27, 2004) 8/ & & & & & & 0.734 & \\
\hline Nominal effective rate $(2000=100)$ & 103.0 & 100.0 & 100.5 & 101.2 & 104.2 & 104.8 & $\ldots$ \\
\hline Real effective rate $(2000=100) 9 /$ & 103.3 & 100.0 & 101.1 & 100.2 & 102.6 & 102.7 & $\ldots$ \\
\hline
\end{tabular}

Sources: Data provided by the authorities; and Fund staff estimates and projections.

$1 /$ Contribution to growth.

2/ Percent of the labor force.

3/ Harmonized consumer price index.

4/ Economy wide.

5/ Since 1999, Euro rate.

6/ Includes UMTS license revenue of 0.2 percent of GDP in 2001; and proceeds from the transfer of Belgacom's pension fund of 1.9 percent of GDP in 2003.

7/ Excludes UMTS license revenue of 0.2 percent of GDP in 2001; and proceeds from the transfer of Belgacom's pension fund of 1.9 percent of GDP in 2003.

8/ Belgium entered the final stage of EMU on January 1, 1999 at a rate of 40.3399 Belgian francs to the euro.

9/ Based on relative normalized unit labor costs in manufacturing. 
Table 2. Belgium: Operations of the General Government, 1997-2003

\begin{tabular}{|c|c|c|c|c|c|c|c|}
\hline & 1997 & 1998 & 1999 & 2000 & 2001 & 2002 & 2003 \\
\hline Revenue & 49.4 & 50.0 & 49.6 & 49.5 & 49.9 & 50.3 & 51.3 \\
\hline Tax revenue & 44.8 & 45.5 & 45.1 & 45.1 & 45.2 & 45.6 & 44.9 \\
\hline Direct taxes & 17.1 & 17.6 & 17.1 & 17.4 & 17.6 & 17.6 & 17.0 \\
\hline Personal income tax & 14.0 & 14.0 & 13.6 & 13.9 & 14.3 & 14.3 & 13.8 \\
\hline Company income tax & 3.0 & 3.6 & 3.4 & 3.4 & 3.3 & 3.2 & 3.0 \\
\hline Other direct taxes & 0.1 & 0.1 & 0.1 & 0.1 & 0.1 & 0.1 & 0.1 \\
\hline Indirect taxes & 12.9 & 12.9 & 13.2 & 13.1 & 12.7 & 12.9 & 12.9 \\
\hline Social contributions & 14.5 & 14.6 & 14.4 & 14.1 & 14.4 & 14.6 & 14.5 \\
\hline Other taxes & 0.4 & 0.4 & 0.4 & 0.5 & 0.5 & 0.5 & 0.5 \\
\hline Nontax revenue & 4.7 & 4.6 & 4.5 & 4.4 & 4.7 & 4.7 & 6.5 \\
\hline Expenditure & 51.4 & 50.7 & 50.0 & 49.3 & 49.3 & 50.2 & 51.0 \\
\hline Primary expenditure & 43.4 & 43.1 & 43.0 & 42.6 & 42.8 & 44.2 & 45.5 \\
\hline Current expenditure & 40.3 & 40.2 & 39.9 & 39.4 & 40.4 & 41.7 & 42.6 \\
\hline Wages & 11.7 & 11.6 & 11.6 & 11.4 & 11.6 & 12.0 & 12.1 \\
\hline Operations and maintenance & 2.9 & 2.9 & 3.0 & 3.0 & 3.2 & 3.4 & 3.4 \\
\hline Social transfers & 22.3 & 22.1 & 21.7 & 21.5 & 22.0 & 22.6 & 23.3 \\
\hline Old age & 8.7 & 8.6 & 8.4 & 8.3 & 8.4 & 8.5 & 8.6 \\
\hline Health & 5.4 & 5.5 & 5.6 & 5.6 & 5.9 & 5.9 & 6.2 \\
\hline Unemployment & 2.1 & 2.0 & 1.9 & 1.8 & 1.8 & 2.0 & 2.1 \\
\hline Other social transfer & 6.1 & 5.9 & 5.8 & 5.8 & 5.9 & 6.2 & 6.3 \\
\hline Subsidies to enterprises & 1.4 & 1.4 & 1.4 & 1.5 & 1.6 & 1.5 & 1.6 \\
\hline Other transfers & 2.1 & 2.1 & 2.1 & 2.0 & 2.0 & 2.1 & 2.2 \\
\hline Capital expenditure & 3.1 & 2.9 & 3.2 & 3.1 & 2.4 & 2.6 & 2.9 \\
\hline Interest & 8.0 & 7.6 & 7.0 & 6.8 & 6.6 & 6.0 & 5.4 \\
\hline Overall balance & -2.0 & -0.7 & -0.4 & 0.2 & 0.6 & 0.1 & 0.4 \\
\hline Primary balance & 6.0 & 7.0 & 6.6 & 6.9 & 7.2 & 6.1 & 5.8 \\
\hline \multicolumn{8}{|l|}{ Memorandum items: } \\
\hline Structural balance & -2.0 & -0.7 & -1.0 & -1.6 & -0.7 & -0.1 & -0.9 \\
\hline Central government balance & -2.4 & -1.6 & -1.5 & -0.4 & -0.8 & -0.2 & 0.4 \\
\hline Gross public debt (Maastricht definition) & 124.1 & 118.9 & 114.4 & 109.2 & 108.0 & 105.4 & 99.9 \\
\hline
\end{tabular}

Sources: Data provided by the Belgian authorities; and Fund staff projections. 
Table 3. Belgium: Public Sector Debt Sustainability Framework, 1999-2009

(In percent of GDP; unless otherwise indicated)

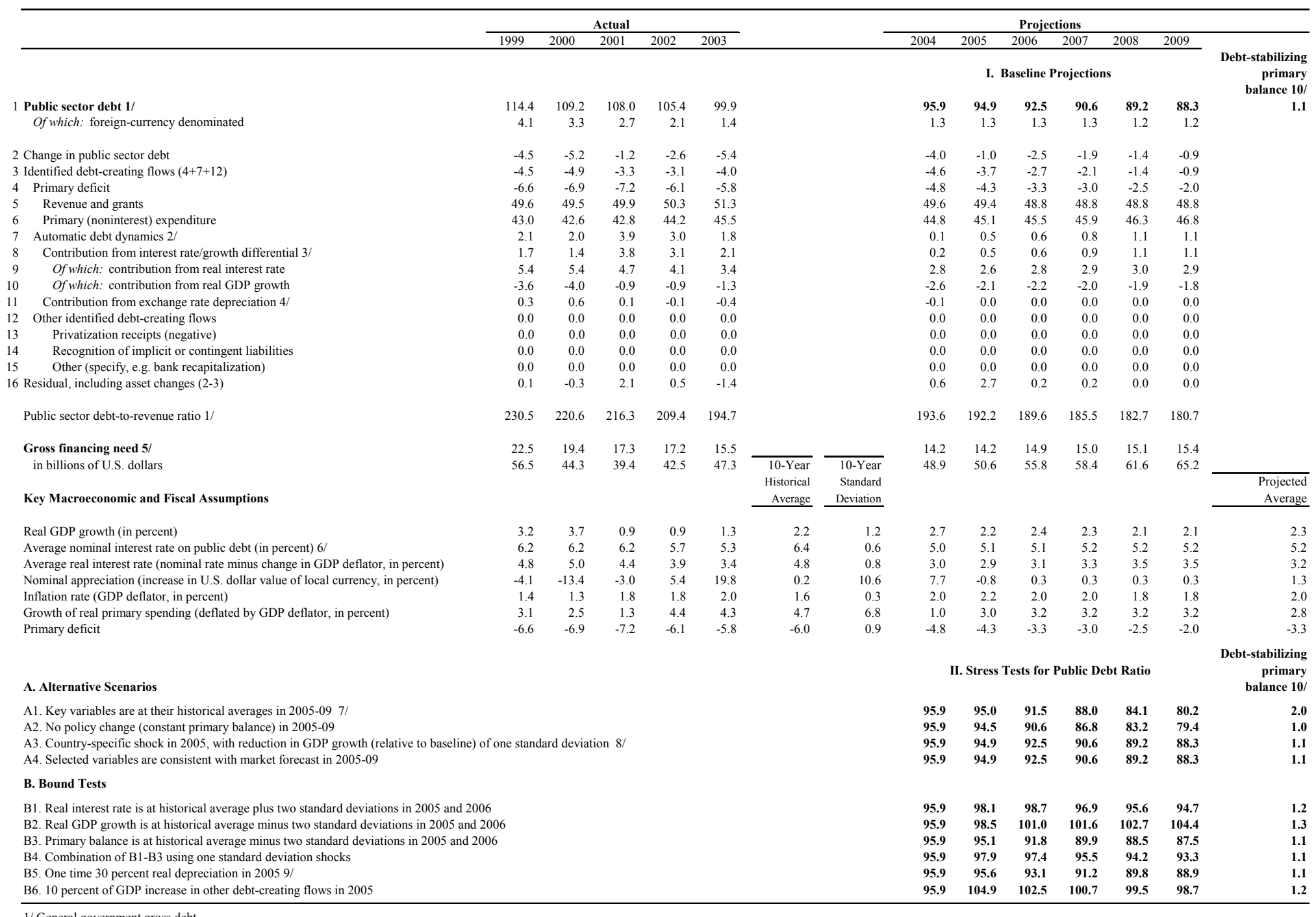

1/ General government gross debt.
$2 /$ Derived as $[(\mathrm{r}-\pi(1+\mathrm{g})-\mathrm{g}+\alpha \varepsilon(1+\mathrm{r})](1+\mathrm{g}+\pi+\mathrm{g} \pi))$ times previous period debt ratio, with $\mathrm{r}=$ interest rate; $\pi=$ growth rate of GDP deflator; $\mathrm{g}=$ real GDP growth rate; $\alpha=$ share of foreign-currency
denominated debt; and $\varepsilon=$ nominal exchange rate depreciation (measured by increase in local currency value of U.S. dollar).

$3 /$ The real interest rate contribution is derived from the denominator in footnote $2 /$ as $r-\pi(1+g)$ and the real growth contribution as $-\mathrm{g}$

$4 /$ The exchange rate contribution is derived from the numerator in footnote $2 /$ as $\alpha \varepsilon(1+r)$.

5/ Defined as public sector deficit, plus amortization of medium- and long-term public sector debt, plus short-term debt at end of previous period.

7/ The key variables include real GDP growh, real interest rate; and primary balance in percent of GDP

$8 /$ The implied change in other key variables under this scenario is discussed in the text.

9/ Real depreciation is defined as nominal depreciation (measured by percentage fall in dollar value of local currency) minus domestic inflation (based on GDP deflator).

CInternational Monetary Fund. Not for Redistribution 
Table 4. Belgium: Fiscal Scenarios, 2001-07

(In percent of GDP; unless otherwise indicated)

\begin{tabular}{|c|c|c|c|c|c|c|c|}
\hline & \multirow[b]{2}{*}{2001} & \multirow[b]{2}{*}{2002} & \multirow[b]{2}{*}{2003} & \multirow{2}{*}{$\begin{array}{r}\text { Est. } \\
2004\end{array}$} & \multicolumn{3}{|c|}{ Proj. } \\
\hline & & & & & 2005 & 2006 & 2007 \\
\hline \multicolumn{8}{|l|}{ Current policies (A) } \\
\hline Revenue & 49.9 & 50.3 & 51.3 & 49.6 & 49.4 & 48.8 & 48.8 \\
\hline Expenditure & 49.3 & 50.2 & 51.0 & 49.6 & 49.8 & 50.1 & 50.5 \\
\hline Primary expenditure & 42.8 & 44.2 & 45.5 & 44.8 & 45.1 & 45.5 & 45.9 \\
\hline Interest payments & 6.6 & 6.0 & 5.4 & 4.8 & 4.7 & 4.7 & 4.7 \\
\hline Balance & 0.6 & 0.1 & 0.4 & 0.0 & -0.4 & -1.4 & -1.7 \\
\hline Structural balance $1 /$ & -0.7 & -0.1 & -0.9 & 0.3 & -0.1 & -1.3 & -1.7 \\
\hline Primary balance & 7.2 & 6.1 & 5.8 & 4.8 & 4.3 & 3.3 & 3.0 \\
\hline Structural primary balance 1 / & 6.0 & 5.9 & 4.5 & 5.1 & 4.6 & 3.4 & 3.0 \\
\hline Debt & 108.0 & 105.4 & 99.9 & 95.9 & 94.9 & 92.5 & 90.6 \\
\hline \multicolumn{8}{|l|}{ Memorandum items (in percent): } \\
\hline Real primary expenditure growth & 1.3 & 4.4 & 4.3 & 1.0 & 3.0 & 3.2 & 3.2 \\
\hline Real discretionary spending growth & -0.5 & 5.2 & 4.2 & -2.3 & 4.1 & 2.7 & 2.7 \\
\hline Output gap & 1.2 & -0.1 & -1.0 & -0.5 & -0.4 & -0.1 & 0.0 \\
\hline GDP growth & 0.9 & 0.9 & 1.3 & 2.7 & 2.2 & 2.4 & 2.3 \\
\hline \multicolumn{8}{|c|}{ Government scenario; Stability Program (B) } \\
\hline Revenue & 49.9 & 50.3 & 51.3 & 49.6 & 49.4 & 49.0 & 49.1 \\
\hline Expenditure & 49.3 & 50.2 & 51.0 & 49.6 & 49.4 & 49.0 & 48.8 \\
\hline Primary expenditure & 42.8 & 44.2 & 45.5 & 44.8 & 44.9 & 44.6 & 44.6 \\
\hline Interest payments & 6.6 & 6.0 & 5.4 & 4.8 & 4.5 & 4.4 & 4.2 \\
\hline Balance & 0.6 & 0.1 & 0.4 & 0.0 & 0.0 & 0.0 & 0.3 \\
\hline Structural balance 2/ & -0.7 & -0.1 & 1.0 & 0.4 & 0.0 & -0.2 & 0.5 \\
\hline Primary balance & 7.2 & 6.1 & 5.7 & 4.8 & 4.5 & 4.4 & 4.5 \\
\hline Structural primary balance 1 / & 6.0 & 5.9 & 6.4 & 5.3 & 4.6 & 4.2 & 4.5 \\
\hline Debt & 108.0 & 105.4 & 99.9 & 95.9 & 94.8 & 91.0 & 87.3 \\
\hline \multicolumn{8}{|l|}{ Memorandum items (in percent): } \\
\hline Real primary expenditure growth & 1.3 & 4.4 & 4.3 & 0.5 & 3.0 & 1.8 & 2.1 \\
\hline GDP growth & 0.9 & 0.9 & 1.3 & 2.4 & 2.5 & 2.5 & 2.1 \\
\hline \multicolumn{8}{|l|}{ Reform and consolidation (C) } \\
\hline Revenue & 49.9 & 50.3 & 51.3 & 49.6 & 49.4 & 48.8 & 48.8 \\
\hline Expenditure & 49.3 & 50.2 & 51.0 & 49.6 & 49.3 & 49.1 & 48.8 \\
\hline Primary expenditure & 42.8 & 44.2 & 45.5 & 44.8 & 44.6 & 44.4 & 44.2 \\
\hline Interest payments & 6.6 & 6.0 & 5.4 & 4.8 & 4.7 & 4.7 & 4.6 \\
\hline Balance & 0.6 & 0.1 & 0.4 & 0.0 & 0.1 & -0.3 & 0.0 \\
\hline Structural balance 1/ & -0.7 & -0.1 & -0.9 & 0.3 & 0.5 & 0.0 & 0.3 \\
\hline Primary balance & 7.2 & 6.1 & 5.8 & 4.8 & 4.8 & 4.4 & 4.6 \\
\hline Structural primary balance $1 /$ & 6.0 & 5.9 & 4.4 & 5.0 & 5.1 & 4.6 & 4.8 \\
\hline Debt & 108.0 & 105.4 & 99.9 & 95.9 & 94.5 & 91.1 & 87.6 \\
\hline \multicolumn{8}{|l|}{ Memorandum items (in percent): } \\
\hline Real primary expenditure growth & 1.3 & 4.4 & 4.3 & 1.0 & 1.7 & 1.7 & 1.7 \\
\hline Real discretionary spending growth & -0.5 & 5.2 & 4.2 & -2.3 & 1.4 & 1.4 & 1.4 \\
\hline Output gap & 1.2 & -0.1 & -1.0 & -0.5 & -0.5 & -0.4 & -0.3 \\
\hline GDP growth & 0.9 & 0.9 & 1.3 & 2.7 & 2.2 & 2.2 & 2.2 \\
\hline
\end{tabular}

Sources: Data provided by the authorities; and Fund staff projections.

1/ Excluding the effects of the UMTS auctions and the capital transfer resulting from the Belgacom pension fund takeover. takeover. Other nonstructural items and one-off factors have not been excluded, in line with the WEO convention.

2/ Excluding the effects of the UMTS auctions only. 
Table 5. Belgium: Vulnerability Indicators, 2000-04

\begin{tabular}{|c|c|c|c|c|c|}
\hline & 2000 & 2001 & 2002 & 2003 & $2004 / 1 \mathrm{H}$ \\
\hline \multicolumn{6}{|l|}{ External indicators } \\
\hline Exports (annual percentage change, in U.S. dollars) & 2.9 & -0.3 & 5.7 & 20.4 & 11.2 \\
\hline Imports (annual percentage change, in U.S. dollars) & 5.2 & -0.5 & 4.0 & 21.3 & 11.7 \\
\hline Terms of trade (annual percentage change) & -1.3 & -1.0 & 2.2 & 0.6 & 0.0 \\
\hline Current account balance (percent of GDP) & 3.9 & 3.7 & 5.3 & 3.9 & 4.3 \\
\hline \multicolumn{6}{|l|}{ Capital and financial account balance } \\
\hline Inward portfolio investment (debt securities etc.) 1/ & 57.4 & 64.7 & $\ldots$ & $\ldots$ & $\ldots$ \\
\hline Inward foreign direct investment & 108.5 & 24.1 & 24.1 & 24.1 & $\ldots$ \\
\hline Official reserves (in billions of U.S. dollars, end-of-period) 2/ & 10.0 & 11.3 & 11.9 & 11.0 & 11.0 \\
\hline Official reserves in months of imports & 0.6 & 0.7 & 0.7 & 0.6 & 0.5 \\
\hline Exchange rate per U.S. dollar (period average) $3 /$ & 1.083 & 1.116 & 1.059 & 0.884 & 0.823 \\
\hline \multicolumn{6}{|l|}{ Market indicators } \\
\hline \multicolumn{6}{|l|}{ Financial markets indicators } \\
\hline Public sector debt (Maastricht definition) & 109.5 & 108.7 & 106.1 & 103.0 & 101.3 \\
\hline 3-month T-bill yield & 4.0 & 4.2 & 3.2 & 2.2 & 2.0 \\
\hline 3-month T-bill yield (real) & 1.5 & 1.7 & 1.5 & 0.6 & -0.3 \\
\hline Spread of 3-month T-bill over EURIBOR (percentage points) & -0.29 & 0.03 & -0.08 & -0.05 & -0.08 \\
\hline 10 -year government bond rate & 5.6 & 5.1 & 5.0 & 4.2 & 4.3 \\
\hline Government bond yield (real) & 2.9 & 2.7 & 3.4 & 2.7 & 2.5 \\
\hline Spread of 10-year government bond rate with Germany (percentage points) & 0.30 & 0.31 & 0.20 & 0.09 & 0.11 \\
\hline Stock market index (period average) & 2,967 & 2,807 & 2,410 & 1,975 & 2,421 \\
\hline \multicolumn{6}{|l|}{ Credit markets indicators (end-of-period 12-month growth rates) } \\
\hline Credit to the private sector & 3.5 & 1.4 & 1.5 & 3.0 & 1.7 \\
\hline Bank credit to households & 2.4 & -1.1 & 4.1 & 6.8 & 7.0 \\
\hline Mortgages & 7.8 & 2.7 & 7.9 & 11.8 & 11.7 \\
\hline Bank credit to nonfinancial enterprises & 4.4 & -1.2 & -3.0 & -4.1 & 1.9 \\
\hline Number of credit institutions & 119 & 113 & 111 & 109 & 107 \\
\hline Off-balance-sheet operations of credit institutions (in billions of euros) & 2,611 & 3,237 & 4,297 & 4,625 & 6,015 \\
\hline Interest rates & 2,071 & 2,640 & 3,627 & 3,912 & 5,258 \\
\hline Foreign exchange & 358 & 368 & 432 & 468 & 558 \\
\hline Other & 182 & 229 & 238 & 245 & 199 \\
\hline \multicolumn{6}{|l|}{ Financial sector risk indicators } \\
\hline Risk-based capital asset ratio 4/ 5/ & 11.9 & 12.9 & 13.1 & 12.8 & 12.3 \\
\hline \multicolumn{6}{|l|}{ Rate of return on average equity 5 / } \\
\hline Banking sector & 20.4 & 13.7 & 11.8 & 13.6 & $9.7 *$ \\
\hline Insurance sector & 21.5 & 12.1 & -10.4 & 7.3 & $\ldots$ \\
\hline Loan/deposit ratio & 77.8 & 76.4 & 80.0 & 81.0 & 86.0 \\
\hline Nonperforming loans/total loans & 2.7 & 2.9 & 2.9 & 2.6 & 2.2 \\
\hline Provisions and write-offs/nonperforming loans & 57.0 & 57.0 & 51.8 & 52.8 & 53.5 \\
\hline Share of mortgage credit in bank credit to the private sector & 32.4 & 34.0 & 36.3 & 40.0 & 41.2 \\
\hline Foreign assets of the banking sector (in billions of U.S. dollars, end-of-period) 6/ & 108.2 & 127.0 & 164.2 & 194.3 & 217.6 \\
\hline Foreign liabilities of the banking sector (in billions of U.S. dollars, end-of-period) & 163.9 & 176.3 & 199.0 & 236.4 & 270.6 \\
\hline Cost-income ratio of the banking system & 72.2 & 74.1 & 74.7 & 73.9 & 68.2 \\
\hline Insurance sector coverage ratio $7 /$ & 265.0 & 276.0 & 254.1 & 253.3 & 260.0 \\
\hline \multicolumn{6}{|l|}{ Sectoral risk indicators } \\
\hline \multicolumn{6}{|l|}{ Household sector } \\
\hline Household savings ratio 8/ & 15.0 & 16.9 & 17.5 & 16.3 & $\ldots$ \\
\hline Household financial savings ratio & 9.7 & 9.1 & 9.1 & 9.2 & $\cdots$ \\
\hline \multicolumn{6}{|l|}{ Corporate sector } \\
\hline Profitability of business sector & 37.2 & 35.4 & 35.4 & 35.7 & $\ldots$ \\
\hline Investment ratio & 23.5 & 21.8 & 19.3 & 19.2 & $\ldots$ \\
\hline Savings ratio & 24.5 & 21.9 & 20.5 & 21.6 & $\ldots$ \\
\hline Self-financing ratio & 104.0 & 100.4 & 105.8 & 112.3 & $\ldots$ \\
\hline
\end{tabular}

Sources: Data provided by the authorities; IMF, International Financial Statistics, and IMF Research department.

1/ Capital account data cover the definition of the Belgium-Luxembourg Economic Union (BLEU).

2/ Reserves and foreign liabilities refer to the Belgian central bank, both before and after EMU.

3/ Euro per dollar. The fixed BEF/euro conversion rate is 40.3399 .

4/ On a consolidated basis and after distribution of profits.

5 / Excludes foreign subsidiaries in Belgium.

6/ Banking institutions.

7/ Available solvency ratio over required solvency ratio.

8/ Excluding nonprofit institutions.

*Nonannualized data 
Belgium: Fund Relations

(As of November 30, 2004)

I. Membership Status: Joined 12/27/45; Article VIII

II. General Resources Account:

Quota

Fund holdings of currency

Reserve position in Fund

SDR Million

$4,605.20$

$3,043.73$

$1,561.48$

SDR Million

485.25

263.58
\% Quota

100.00

66.09

33.91

$\%$ Allocation

100.00

54.32

[Designation plan]

IV. Outstanding Purchases and Loans: None

V. Latest Financial Arrangements: None

VI. Projected Payments to Fund (SDR Million; based on existing use of resources and present holdings of SDRs):

Forthcoming
$\begin{array}{llll}\underline{2004} \quad \underline{2005} \quad \underline{2006} \quad \underline{2007} \quad \underline{2008}\end{array}$

Principal

Charges/interest

Total

$\frac{4.90}{4.90} \quad \frac{4.94}{4.94} \quad \frac{4.94}{4.94} \quad \frac{4.95}{4.95}$

\section{Exchange Rate Arrangement:}

Until December 31, 1998, Belgium formed a monetary union with Luxembourg in which the Belgian and Luxembourg francs were at par, while also participating in the exchange rate mechanism of the European Monetary System. Belgium entered the final stage of European Economic and Monetary Union on January 1, 1999 at a rate of 40.3399 Belgian francs to the euro.

\section{Article IV Consultations:}

Belgium is on the 12-month cycle; the last consultation was completed on February 13, 2004.

IX. Belgium retains restrictions vis-à-vis Iraq, the Socialist Peoples' Libyan Arab Jamahiriya, and the Federal Republic of Yugoslavia (Serbia and Montenegro) pursuant to UN Security Council resolutions 661, 883, and 757, respectively. These restrictions have 
been notified to the Fund pursuant to Decision No. 144-(52/51). The residual restrictions vis-à-vis the Federal Republic of Yugoslavia (Serbia and Montenegro) relate solely to balances of the former National Bank of Yugoslavia that remain frozen, since they are subject to unresolved legal claims. 
Belgium: Core Statistical Indicators

As of January 5, 2005

\begin{tabular}{|c|c|c|c|c|c|c|c|}
\hline & $\begin{array}{l}\text { Exchange } \\
\text { Rates }\end{array}$ & $\begin{array}{l}\text { Interest } \\
\text { Rates }\end{array}$ & $\begin{array}{l}\text { Consumer } \\
\text { Price } \\
\text { Index }\end{array}$ & $\begin{array}{l}\text { Exports/ } \\
\text { Imports }\end{array}$ & $\begin{array}{l}\text { Current } \\
\text { Account } \\
\text { Balance }\end{array}$ & $\begin{array}{c}\text { Overall } \\
\text { Government } \\
\text { Balance }\end{array}$ & GDP/GNP \\
\hline $\begin{array}{l}\text { Date of Latest } \\
\text { Observation }\end{array}$ & $1 / 5 / 05$ & $1 / 5 / 05$ & $11 / 04$ & $10 / 04$ & $9 / 04$ & 2003 & Q3/04 \\
\hline Date Received & $1 / 5 / 05$ & $1 / 5 / 05$ & $1 / 2 / 05$ & $11 / 10 / 04$ & $11 / 10 / 04$ & $5 / 30 / 04$ & $12 / 8 / 04$ \\
\hline $\begin{array}{l}\text { Frequency of } \\
\text { Data }\end{array}$ & Daily & Daily & Monthly & Monthly & Quarterly & Annually & Quarterly \\
\hline $\begin{array}{l}\text { Frequency of } \\
\text { Reporting }\end{array}$ & Daily & Daily & Monthly & Monthly & Quarterly & Annually & Quarterly \\
\hline $\begin{array}{l}\text { Source of } \\
\text { Update }\end{array}$ & Reuters & Reuters & Eurostat & NBB & NBB & NBB & NBB \\
\hline $\begin{array}{l}\text { Mode of } \\
\text { Reporting }\end{array}$ & Electronic & Electronic & Electronic & $\begin{array}{c}\text { NBB } \\
\text { Website }\end{array}$ & $\begin{array}{c}\text { NBB } \\
\text { Website }\end{array}$ & $\begin{array}{c}\text { NBB } \\
\text { website }\end{array}$ & $\begin{array}{c}\text { NBB } \\
\text { Website }\end{array}$ \\
\hline Confidentiality & Public & Public & Public & Public & Public & Public & Public \\
\hline $\begin{array}{l}\text { Frequency of } \\
\text { Publication }\end{array}$ & Daily & Daily & Monthly & Monthly & Monthly & Annually & Quarterly \\
\hline
\end{tabular}

Key publicly accessible websites for macroeconomic data and analysis are:

National Statistics Agency www.statbel.fgov.be

National Bank of Belgium. www.nbb.be

Federal Planning Bureau www.plan.be

Commission for Banking, Finance, and Insurance www.cbfa.be

High Finance Council. www.docufin.be Central Economic Council www.ccecrb.fgov.be 


\section{INTERNATIONAL MONETARY FUND}

Public Information Notice

EXTERNAL

RELATIONS

DEPARTMENT

Public Information Notice (PIN) No. 05/26

International Monetary Fund

FOR IMMEDIATE RELEASE

March 3, 2005

$70019^{\text {th }}$ Street, NW

Washington, D. C. 20431 USA

\section{IMF Executive Board Concludes 2004 Article IV Consultation with Belgium}

On February 18, 2005, the Executive Board of the International Monetary Fund (IMF) concluded the Article IV Consultation with Belgium. ${ }^{1}$

\section{Background}

During the recent upswing, growth has been comparatively robust, propelled by strong household spending and supported by the global recovery as well as macroeconomic policies. Tax cuts and wage increases have sustained disposable income growth, while household savings resumed a declining trend, amid improvements in the economic outlook and public finances. Private consumption was also supported by low interest rates and rising housing prices. The repatriation of assets due to the implementation of the EU savings taxation directive and a tax amnesty may also have played a role. Monetary conditions have remained accommodating despite the euro's appreciation. Countercyclical support from the fiscal policy stance was masked by large, one-off deficit-reducing measures.

In the staff's view, economic growth is expected to continue at a healthy pace in 2005 , driven by private consumption as well as a likely strengthening of corporate investment and employment growth. Downside risks lie in high oil prices, weaker demand in key trading partners, and further appreciation of the euro. Weaker-than-expected employment growth or sagging confidence could also dampen growth prospects. With actual GDP expected to remain below potential,

\footnotetext{
${ }^{1}$ Under Article IV of the IMF's Articles of Agreement, the IMF holds bilateral discussions with members, usually every year. A staff team visits the country, collects economic and financial information, and discusses with officials the country's economic developments and policies. On return to headquarters, the staff prepares a report, which forms the basis for discussion by the Executive Board. At the conclusion of the discussion, the Managing Director, as Chairman of the Board, summarizes the views of Executive Directors, and this summary is transmitted to the country's authorities.
} 
there are no underlying inflationary pressures, though indirect tax increases and higher energy prices will add to headline inflation into 2005. There could, however, be some wage drift in the wake of the 2005-06 interprofessional wage agreement, which also includes indexation. In the long run, demographic pressures are expected to reduce potential growth.

The authorities' strategy to cope with the adverse consequences of aging on growth and the budget consists of fiscal adjustment, pension reform, and measures to raise labor utilization. As a result of the buildup of large primary surpluses, the public-debt-to-GDP ratio has been declining steadily. Over the past five years, the budget has remained in balance, to a large extent due to the use of favorable one-time measures during the cyclical downswing.

Achieving balance in 2005 continues to rely on some one-off measures. Meanwhile, the primary surplus declined in recent years as interest savings were used for tax cuts and increases in primary spending, including on health care and law and order. There is consensus on the need to build up fiscal surpluses over the medium term.

Reform of the main pension system is largely complete, with benefits of the pay-as-you-go pillar relatively low, though the decision about when to retire is not actuarially fair. Reform of the early retirement regime, key to prevent premature exit from the labor force by older workers, is scheduled for early 2005 , but the option will remain in case of enterprise restructurings.

To boost employment, the authorities have cut the tax wedge on labor, introduced an earned income tax credit, and strengthened job search requirements and verification.

\section{Executive Board Assessment}

Executive Directors commended the Belgian authorities for the economy's sustained strong performance, despite slow growth in several key trading partners. Directors attributed this impressive performance to the economy's sound fundamentals and prudent fiscal management as reflected in a steadily declining debt ratio. They singled out as exemplary the authorities' track record of maintaining the budget in balance or surplus, while implementing a program of cuts in taxes and social security contributions, geared at improving labor market performance.

Directors observed that reforms have begun to address the implications of impending population aging and increasing global competitive pressures, but encouraged the authorities to continue to strengthen policies on a broad front. Pointing to Belgium's still high debt ratio, they saw a need for further fiscal adjustment to help prefund aging costs while avoiding future tax increases or cuts in already modest pension benefits. Similarly, attaining higher employment rates will be essential to raise growth, sustain fiscal consolidation, and preserve favorable social outcomes.

Directors concurred that the growth outlook remains auspicious, though subject to some downside risks. Externally, high oil prices, softer demand in major trading partners, and further euro appreciation can stifle growth. Domestically, weaker-than-expected employment or sagging confidence can dampen growth prospects. Directors observed that inflation is expected to remain low. To preserve competitiveness and avoid cost-push pressures, they encouraged 
social partners to moderate wages and strive for higher productivity through more flexible work arrangements.

Directors supported the authorities' fiscal objectives, in particular of balancing the budgets in 2005-06 and gradually building surpluses thereafter, to about 1.5 percent of GDP by 2011. Such a strategy would allow a substantial part of the cost of aging to be covered through savings on the interest bill. In this regard, Directors saw a need to preserve the current level of the primary surplus.

Directors noted that fiscal efforts would need to be stepped up substantially to achieve these objectives. Against the background of robust economic growth, balancing the budget in 2005 appears feasible, though not without further efforts. In this context, Directors welcomed the authorities' early response to the 2004 spending overruns in health care spending and urged them to implement reforms, over a medium-term horizon, to lower spending growth in this area. They recommended to use information technology and the impending wave of retirements in the civil service for substantial budgetary savings. Directors also saw scope for durable adjustment through a narrowing of entitlements and streamlining of active labor market programs as part of a comprehensive labor market reform.

Directors encouraged the authorities to adopt a multi-year primary expenditure framework as a key tool of fiscal management. They acknowledged that the focus on the year-by-year achievement of nominal targets has been helpful, but it has led to heavy reliance on one-off measures. Adopting an expenditure-based medium-term framework will help establish sustainable ways of reducing public expenditure and enhance transparency. At the same time, Directors recognized that achieving the balanced budget targets in recent years has helped build policy credibility, with attendant improvements in confidence economy wide. In addition, Directors recommended the renewal and strengthening of the internal stability pact between the federal and regional governments to ensure that all regions balance their budgets in the long run and that their decisions do not adversely affect the federal budget.

Directors agreed that boosting labor utilization is a vital component of the strategy to deal with population aging and requires several actions. Overall, there is a need for moderation of wage increases and a modification of the collective bargaining system in the medium term, in particular by removing wage indexation and introducing more flexibility in the determination of wages and work arrangements at the enterprise level. Directors felt that the wage norm agreed in the 2005-06 collective agreement was on the high side. To prevent the premature exit of older workers from the labor force, Directors recommended making the retirement decision actuarially fair and phasing out the early retirement programs. For the young and less skilled, Directors welcomed targeted cuts in social security contributions and childcare costs, the earned income tax credit, the tightening of job search requirements, and the increase in job search assistance. To buttress this approach, they felt that the duration of unemployment benefits should be limited and that active labor market programs should be streamlined. A number of Directors pointed to the need to preserve social consensus in implementing these reforms. Noting that an efficient education system is vital to increase employment, 
Directors underscored that further attention to education and vocational training will help workers develop the skills needed to adjust to a changing job context.

Directors encouraged the authorities to extend the ongoing progress of improving the functioning of product markets to all regions and areas, ensuring that it benefits the consumer. In this context, they saw the establishment of a new competition authority as beneficial and recommended a gradual reduction of railway subsidies. The authorities were also encouraged to introduce more competition into the energy and telecommunications sectors.

Directors welcomed the progress in reducing procedures involved in business start-ups. They encouraged the authorities to continue to lower the administrative burden on enterprises and taxpayers, making full use of available information technology.

Directors observed that financial sector performance has improved overall, though the life insurance sector remains vulnerable to interest rate developments. They commended the authorities on the merger of banking and insurance supervisory agencies, which they felt should lead to an improvement of supervision of the banking-insurance conglomerates. In this context, Directors welcomed the timely initiation of the Financial Sector Stability Assessment, to be completed with the next consultation. Directors supported the regular publication by the central bank of financial stability reviews, which has contributed to transparency and market discipline.

Directors welcomed Belgium's efforts to combat money laundering and terrorism financing, its adherence to antibribery initiatives, and its support for multilateral trade liberalization. They praised the sharp increase in official development assistance and the authorities' commitment to raise it to the UN target.

Public Information Notices (PINs) form part of the IMF's efforts to promote transparency of the IMF's views and analysis of economic developments and policies. With the consent of the country (or countries) concerned, PINs are issued after Executive Board discussions of Article IV consultations with member countries, of its surveillance of developments at the regional level, of post-program monitoring, and of ex post assessments of member countries with longer-term program engagements. PINs are also issued after Executive Board discussions of general policy matters, unless otherwise decided by the Executive Board in a particular case. 
Belgium: Selected Economic Indicators

Real economy (change in percent)

Real GDP
Domestic demand
CPI
Unemployment rate (in percent)
Public finance (percent of GDP)

$\begin{array}{lll}0.9 & 0.9 & 1.3\end{array}$

2.7

2.2

$0.2 \quad 0.6$

1.6

3.1

2.5

$2.4 \quad 1.6$

1.5

1.9

2.2

$6.7 \quad 7.3$

8.1

8.3

8.2

General government balance

Structural balance

Primary balance

$\begin{array}{lll}0.6 & 0.1 & 0.3\end{array}$

$0.0 \quad-0.4$

$-0.7$

$-0.1$

$-0.9$

0.3

$-0.1$

General government debt

7.2

6.1

5.7

4.8

4.3

$\begin{array}{lllll}108.0 & 105.4 & 99.9 & 95.9 & 94.9\end{array}$

Interest rates (percent)

Money market rate (3 months)

Government bond yield

$\begin{array}{lll}4.3 & 3.3 & 2.2\end{array}$

$\begin{array}{lll}5.1 & 5.0 & 4.2\end{array}$

2.2

4.3

Balance of payments (percent of GDP)

Trade balance

$2.4 \quad 3.6$

3.1

3.5

3.7

Current account

Official reserves (US\$ billion)

Exchange rate

Exchange rate regime

Euro per U.S. dollar (January 25, 2005)

$\begin{array}{lll}3.7 & 5.3 & 3.8\end{array}$

3.9

$\begin{array}{llll}11.9 & 11.0 & 11.0 & 10.4\end{array}$

Nominal effective rate $(2000=100$, ULC based)

Real effective rate $(2000=100$, ULC based)

Member of EMU

0.769

$\begin{array}{llll}100.0 & 100.5 & 101.2 & 104.2\end{array}$

$\begin{array}{llll}100.0 & 101.1 & 100.2 & 102.6\end{array}$

Sources: Data provided by the Belgian authorities, and IMF staff projections.

1/ Staff estimates and projections. 